\title{
Nandrolone Decanoate: Use, Abuse and Side Effects
}

\author{
Federico Giuseppe Patanè ${ }^{1,+}$, Aldo Liberto ${ }^{1,+}$, Andreana Nicoletta Maria Maglitto ${ }^{1}$, \\ Pasquale Malandrino ${ }^{1}$, Massimiliano Esposito ${ }^{1}$, Francesco Amico ${ }^{1}$, Giuseppe Cocimano ${ }^{1}$, \\ Giuseppe Li Rosi ${ }^{2}$, Dario Condorelli ${ }^{1}$, Nunzio Di Nunno ${ }^{3} \mathbb{D}$ and Angelo Montana ${ }^{1, *(\mathbb{D})}$ \\ 1 Legal Medicine, Department of Medical, Surgical and Advanced Technologies, "G.F. Ingrassia”, \\ University of Catania, 95123 Catania, Italy; federicopatane90@gmail.com (F.G.P.); \\ aldoliberto@gmail.com (A.L.); andreana.maglitto1992@gmail.com (A.N.M.M.); \\ pasqualemalandrino@gmail.com (P.M.); massimiliano.esposito91@gmail.com (M.E.); \\ francescoamico08@gmail.com (F.A.); peppecocimano@hotmail.it (G.C.); dariocondo@hotmail.it (D.C.) \\ 2 Department of Law, Criminology, Magna Graecia University of Catanzaro, 88100 Catanzaro, Italy; \\ lirosigiose@gmail.com \\ 3 Department of History, Society and Studies on Humanity, University of Salento, 73100 Lecce, Italy; \\ nunzio.dinunno@icloud.com \\ * Correspondence: angelomontana49@gmail.com; Tel.: +39-328-765-5428 \\ + These authors contributed equally to this work.
}

Received: 30 September 2020; Accepted: 9 November 2020; Published: 11 November 2020

\begin{abstract}
Background and Objectives: Androgens play a significant role in the development of male reproductive organs. The clinical use of synthetic testosterone derivatives, such as nandrolone, is focused on maximizing the anabolic effects and minimizing the androgenic ones. Class II anabolic androgenic steroids (AAS), including nandrolone, are rapidly becoming a widespread group of drugs used both clinically and illicitly. The illicit use of AAS is diffused among adolescent and bodybuilders because of their anabolic proprieties and their capacity to increase tolerance to exercise. This systematic review aims to focus on side effects related to illicit AAS abuse, evaluating the scientific literature in order to underline the most frequent side effects on AAS abusers' bodies. Materials and Methods: A systematic review of the scientific literature was performed using the PubMed database and the keywords "nandrolone decanoate". The inclusion criteria for articles or abstracts were English language and the presence of the following words: "abuse" or "adverse effects". After applying the exclusion and inclusion criteria, from a total of 766 articles, only 148 were considered eligible for the study. Results: The most reported adverse effects (found in more than $5 \%$ of the studies) were endocrine effects (18 studies, $42 \%$ ), such as virilization, gynecomastia, hormonal disorders, dyslipidemia, genital alterations, and infertility; cardiovascular dysfunctions (six studies, 14\%) such as vascular damage, coagulation disorders, and arteriosus hypertension; skin disorders (five studies, $12 \%$ ) such as pricking, acne, and skin spots; psychiatric and mood disorders (four studies, $9 \%$ ) such as aggressiveness, sleep disorders and anxiety; musculoskeletal disorders (two studies, $5 \%$ ), excretory disorders (two studies, 5\%), and gastrointestinal disorders (two studies, 5\%). Conclusions: Based on the result of our study, the most common adverse effects secondary to the abuse of nandrolone decanoate (ND) involve the endocrine, cardiovascular, skin, and psychiatric systems. These data could prove useful to healthcare professionals in both sports and clinical settings.
\end{abstract}

Keywords: nandrolone decanoate; drug abuse; androgenic steroids; adverse effects; steroid treatment

\section{Introduction}

The name "anabolic androgenic steroids" already suggests their "anabolic" (from Greek $\alpha$ $v \alpha \beta o \lambda \dot{\eta}$ "throw upward") and "androgenic" (Greek $\alpha \gamma \delta \rho o ́ \varsigma$ "of a man" + - $\gamma \varepsilon v \eta \dot{\zeta} \varsigma$ "born") properties. 
Androgens play a significant role in the development of male reproductive organs, such as the prostate, penis, seminal vesicle, ductus deferens, and epididymis. Testosterone is a steroid hormone that has an essential role in the development of the male phenotype and the regulation of reproduction of males. This hormone is effective on puberty, fertility, and sexual function in males [1,2].

Anabolic androgenic steroids (AAS) represent a large group of synthetic derivatives of testosterone, produced to maximize anabolic effects and minimize the androgenic ones [3]. Several structural modifications have been introduced into testosterone in an attempt to maximize the anabolic effect and minimize androgenic effects. Currently, AASs are classified in 3 major classes [4] based on substitution of the base molecule. Class I is related to C-17 esterification. Class II is related to a demethylated group at C-19 and may also have C-17 esters. Class III is related to alkylation at C-17.

The classification of anabolic steroids is given in Table 1.

Table 1. Classification of anabolic androgenic steroids (AAS).

Class Examples

Nandrolone is included in the group of class II AASs, which is composed of 19-nortestosterone-derivates. In general, AASs is a broad and rapidly growing group of synthetic androgens used both clinically and illicitly.

Compared to testosterone propionate, nandrolone decanoate is considered to have strong anabolic effects but weak androgenic effects (potency ratios of 3.29-4.92 and 0.31-0.41). In particular, nandrolone esters are thought to have the highest ratio of anabolic to androgenic effects of any AAS. The low androgenicity of nandrolone decanoate is thought to be due to the fact that nandrolone is inactivated by $5 \alpha$-reductase via transformation into the low-affinity androgen receptor (AR) ligand $5 \alpha$-dihydronandrolone. This is thought to result in a lower incidence and magnitude of side effects.

Nandrolone has very low affinity for human serum sex hormone-binding globulin (SHBG), about $5 \%$ of that of testosterone and $1 \%$ of that of dihydrotestosterone (DHT). It is mainly metabolized by the enzyme $5 \alpha$-reductase, into $5 \alpha$-dihydronandrolone, 19-norandrosterone, and 19-noretiocholanolone, which can be detected in urine [5]. Nandrolone displays a so-called flip-flop pharmacokinetics. This means that the ascending phase of the curve represents the disposition of nandrolone, and the descending part of the curve represents the rate-limiting process of release of nandrolone decanoate from the muscle into the general circulation [6]. In clinical use, nandrolone is applicable in clinical practice for burns, radiation therapy, surgery, trauma, and various forms of anemia [7]. Moreover, it has also been used for the treatment of chronic kidney disease, osteoporosis in postmenopausal women [8], inoperable breast cancer, and for patients on long-term corticosteroid therapy, as well as an adjunct to therapy for conditions characterized by a negative nitrogen balance. The drug is often used 
off-label to preserve lean mass in human immunodeficiency virus (HIV)/acquired immunodeficiency syndrome (AIDS) associated wasting syndrome [9].

The compound is famous not only among adults, but also adolescents because of its anabolic, muscle-building properties [10-13]. Skeletal muscle can be considered as the primary target tissue for the anabolic effects of AAS, which are mediated by androgenic receptors which, after exposure to AAS, are up-regulated, and their number increases with bodybuilding [14]. Therefore, AAS determine an increase in muscle size as a consequence of dose-dependent hypertrophy resulting in an increase of the cross-sectional areas of both type I and type II muscle fibers and myonuclear domains [15]. It is administered via intramuscular injection and is metabolized in a similar manner to testosterone, with conversion into 3-norandrosterone by $5 \alpha$-reductase [16]. The recommended therapeutic dose of ND for humans is $0.4 \mathrm{mg} / \mathrm{kg} /$ day [17]. Its consumption can trigger a series of adverse side effects in the body, both acute and chronic [18]. However, acute adverse effects have also been described, primarily consisting of headaches, fluid retention, gastrointestinal irritation, diarrhea, abdominal pain, jaundice, menstrual abnormalities, and hypertension. The chronic effects of AAS abuse, aside from neuropsychiatric and behavioral effects, include a wide range of somatic consequences. Many organs and systems are targets of AAS action. Consequently, AASs may exert negative effects on reproductive, hepatic, musculoskeletal, endocrine, renal, immunologic, cardiovascular, cerebrovascular, and hematological systems [19-22].

Moreover, it has been reported that AASs can increase tolerance to exercise by making the muscles more capable of resisting overload, thereby shielding them from muscle fiber damage and improving the level of protein synthesis during recovery [23].

Nowadays, especially athletes in power sports such as bodybuilding and weightlifting administer illegally high doses of AASs to increase their muscle mass and improve their overall performance [24]. However, also non-athletes also abuse AASs. Nandrolone decanoate (ND) injection has been classified as a Schedule III controlled substance under the Anabolic Steroids Control Act of 1990 [25]. Due to serious health risks, the nonmedical use of AASs is banned by most sports organizations. In addition, AASs are listed in the WADA (World Anti-Doping Agency) prohibited list [26]. The abuse of these drugs has become a major health problem [27].

The use of AASs in competitive bodybuilding became widespread and was often supervised by physicians who supplied the drugs to the athletes, ensuring what they were injecting was pure while monitoring and minimizing side effects such as infertility, liver toxicity, impaired lipid profiles, high blood pressure, acne, hair loss or gynecomastia. During this time, there was no need for a black market or underground laboratories (UGL) since these drugs were readily available from health professionals. However, the situation dramatically changed after the introduction of the Anabolic Steroid Control Act in 1990, and subsequently reinforced by the Anabolic Steroid Control Act of 2004. In 2014, the Designer Steroid Control Act was enacted in an attempt to close loopholes for slightly modified compounds. These events created an immense demand for black market products, which facilitated the creation of underground laboratory products and importing drugs produced in countries with lax AAS legislations [28].

Even though legitimate pharmaceutical grade AASs can be purchased on the black market via several routes, physician supervision of usage is usually lacking, making a legitimate pharmaceutical product potentially dangerous for uninformed users. Since buying and using AASs (without a medical prescription) is a criminal act in many countries, the AAS user is often reluctant to seek advice from a physician when health issues arise. Indeed, a survey found that AAS users very often have no trust in physicians' knowledge about AASs and typically do not disclose their AAS use to them [29].

The aim of this systematic review is to focus on the side effects related to illicit AAS abuse, evaluating findings in the scientific literature, in order to underline the most frequent side effects on AAS abuser's bodies. 


\section{Materials and Methods}

\subsection{Database Source}

We performed a systematic review of the literature on online resources using the PubMed database for all published articles from 1 January 1900 to 22 July 2020, using the key words: "nandrolone decanoate".

\subsection{Selection of Studies and Data Collection}

A total of 766 articles were retrieved, excluding all duplicated articles, additional exclusion and inclusion criteria were then applied: Articles or abstracts in English containing one of the following words: "Abuse" or "Adverse effects". A total of 479 articles did not meet these criteria and were therefore excluded. From the remaining 278 articles a manual review was performed to remove non-available articles, duplicate articles, articles not relevant for the study, older literature reviews and articles not reporting adverse effects. A total of 148 articles met these inclusion criteria and were considered eligible for the study, while 130 articles were excluded. Studies from the references of the selected articles, and articles not meeting inclusion and exclusion criteria are discussed in this study, but not included in the systematic review. For a more comprehensive review, we included in the discussion the excluded but relevant articles, eventually performing a specific research for key sections. Figure 1 summarizes the flowchart about article selection after the PubMed search. All included articles are listed in Appendix A.

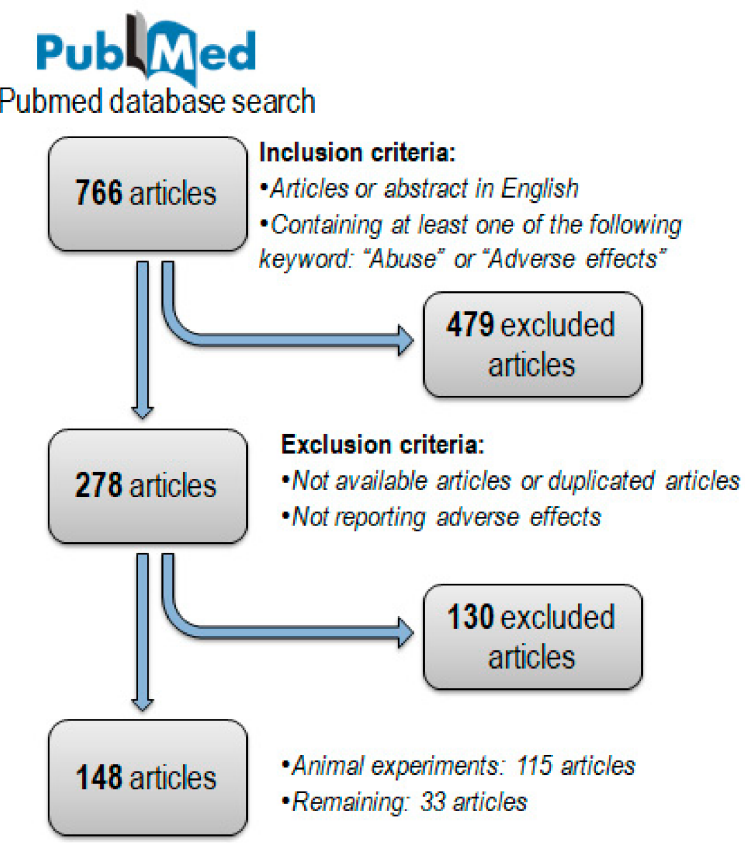

(a)

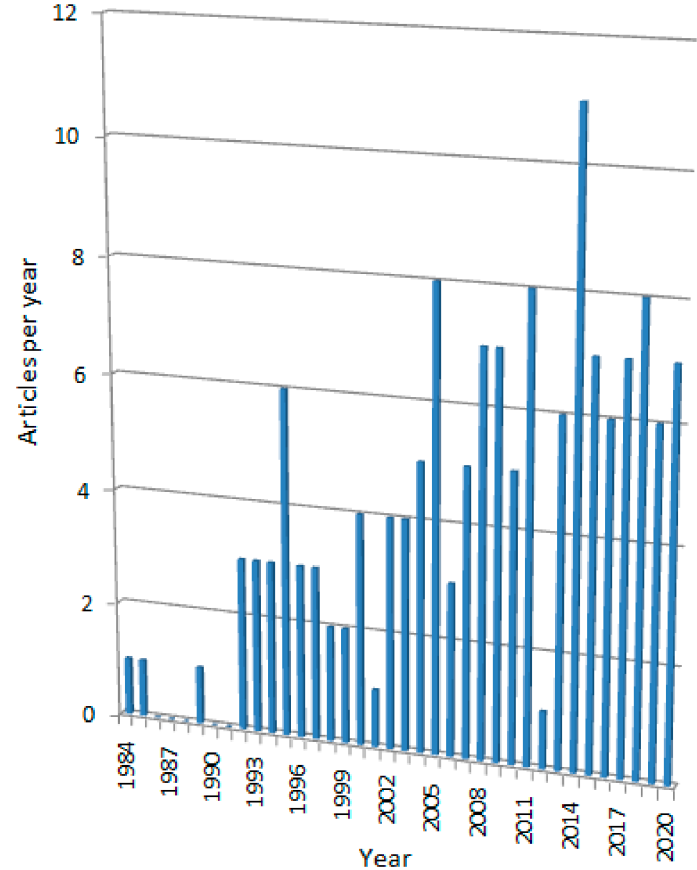

(b)

Figure 1. Included articles search strategy; (a) The flowchart about article selection used for the literature review. (b) Time distribution of included articles: $x$-axis for year; $y$-axis for amount of articles per year.

\section{Results}

A total of 115 studies reported data about animal experiments (for example rats, horses, dogs), while 33 studies reported data about humans (409 subjects, 346 males, 63 females) as shown in Table 2. The subjects mean age was 34.8 years (Standard Deviation: 12.8), as described in 21 articles. Males 
were younger (33.3 years) than females (53.3). Eighteen articles discussed side effects of subjects abusing nandrolone decanoate (without medical prescription), while 15 articles discussed side effects of subjects taking it for medical treatment.

Table 2. Demographic data.

\begin{tabular}{ccc}
\hline & Population & Age (Years) $^{\mathbf{1}}$ \\
\hline Males & $346(87 \%)$ & 33.3 \\
Females & $63(13 \%)$ & 53.3 \\
Total & 409 & 34.8 (S.D. 12.8) \\
\hline Treatment & 313 & \\
Non-treatment & 96 & \\
\hline considered only when both age and gender are reported. S.D.: standard deviation.
\end{tabular}

Adverse effects were studied on these population-based studies. The results are shown in Table 3 and Figure 2. Most reported adverse effects (more than 5\% of the studies) were endocrine (18 studies, 42\%), cardiovascular (six studies, 14\%), skin (five studies, 12\%), psychiatric (four studies, 9\%), musculoskeletal (two studies, 5\%), excretory (two studies, 5\%), and gastrointestinal disorders (two studies, 5\%). In order to list all adverse effects, these were grouped by affected system based on study reports (for example, in psychiatric disorders, we grouped all behavioral, mood, and anxiety symptoms).

Table 3. Adverse effects.

\begin{tabular}{ccc}
\hline & Studies & Common Reports \\
\hline Endocrine & 18 & (virilization, gynecomastia, hormonal disorder, cholesterol and lipid, genital and \\
infertility issues) \\
Cardiovascular & 6 & $\begin{array}{c}\text { (vascular damage, coagulation disorders, arterial hypertension) } \\
\text { (pricking, acne, skin spots) }\end{array}$ \\
Skin & 5 & (aggressiveness, mood disorders, sleep disorders, anxiety) \\
Psychiatric & 4 & (tendon ruptures) \\
Musculoskeletal & 2 & (organ damage) \\
Excretory & 2 & (organ damage, liver adenomas) \\
Gastrointestinal & 2 & (seizures) \\
Neurological & 1 & (chronic infection relapse) \\
Immune & 1 & (sleep apnea syndrome) \\
Respiratory & 1 & (genetic damage) \\
Genetic & 1 &
\end{tabular}

The most common side effects were: endocrine disorders (virilization, gynecomastia, hormonal disorders, cholesterol and lipid disorders, genital and infertility issues); cardiovascular disorders (vascular damage, coagulation disorders, arteriosus hypertension); skin disorders (pricking, acne, skin spots); psychiatric disorders (aggressiveness, mood disorders, sleep disorders, anxiety); musculoskeletal disorders (tendon ruptures); excretory disorders (organ damage); gastrointestinal disorders (organ damage and liver adenomas); neurological disorders (seizures); immune disorders (chronic infection relapse; respiratory disorders (sleep apnea syndrome); genetic disorders (genetic damage).

We also examined the difference between reported side effects between men and women, as well as between the medical administration and abusive use. The most reported side effect concerns the endocrine system for both males and females; reported more frequently for females. The most reported side effects for treatment administration were on the endocrine system (61\%), while the most adverse effects for abusive use were endocrine (19\%), cardiovascular (19\%), and dermatological disorders (19\%). Reports related to males were mixed between treatment and abusive use (45\% were from reports of medical treatment, while 55\% were from reports of illicit or recreational use). In our data, the most common reported side effect was the endocrine system for both males and females $(60 \%$ for females, $37 \%$ for males). We think this result is caused by the number of reports: most examined female cases were secondary to treatment side effects, while male cases were related to both treatment and abuse, as shown in Figures 3 and 4. 


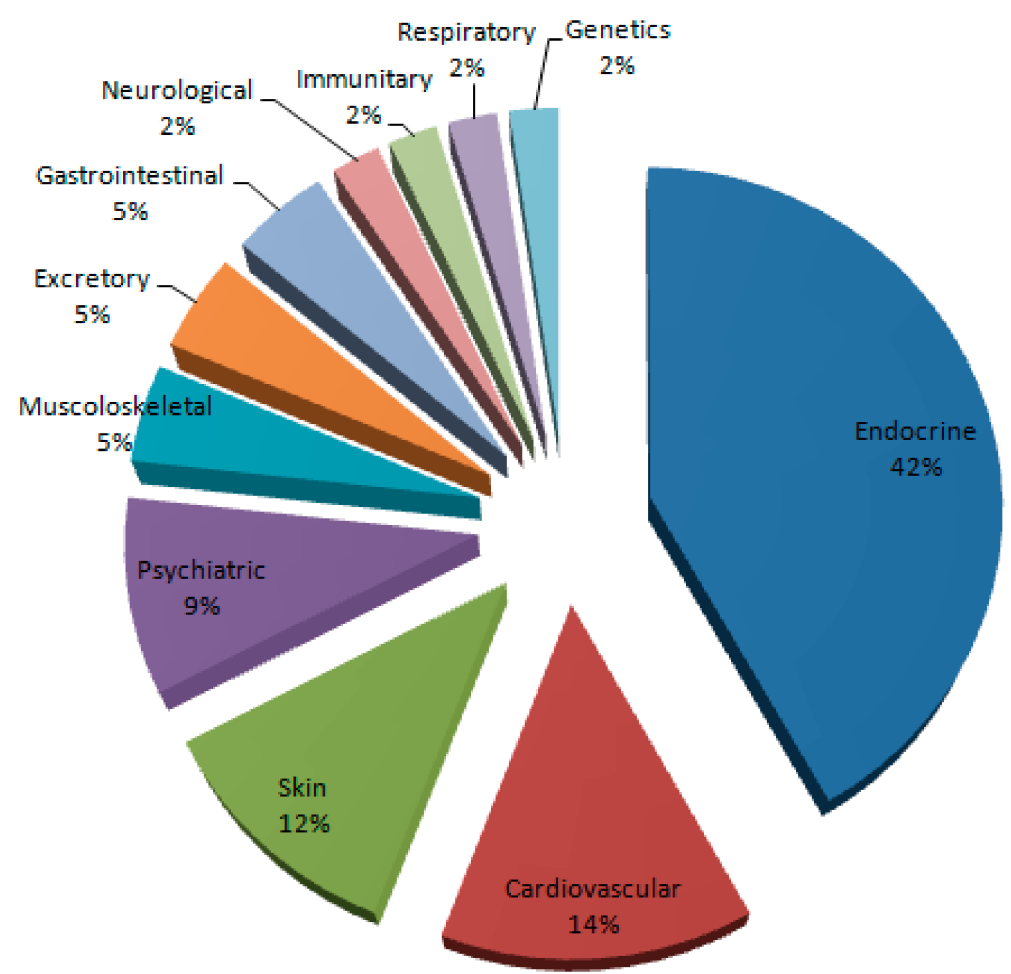

Figure 2. This graph summarizes the adverse effects reported. Endocrine, cardiovascular, skin and psychiatric disorders are the most reported.

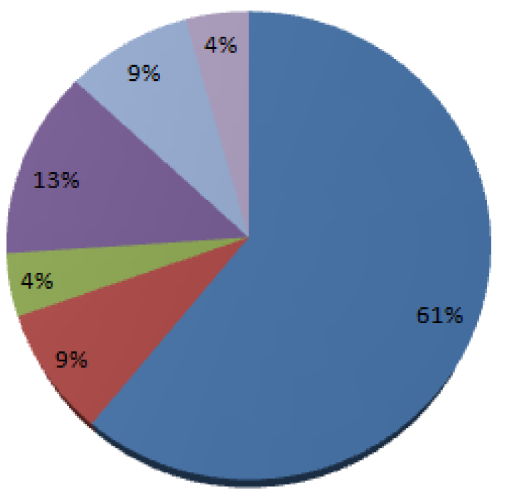

Treatment

(a)

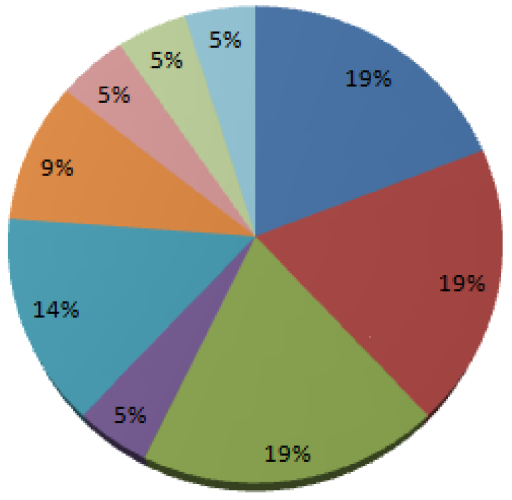

Abuse

(b)
Endrocrine

- Cardiovascular

Dermatological

- Psychiatry

Kidney

Gastrointestinal

- Muscoloskeletal

- Neurological

Immunitary

Respiratory

Genetics

Figure 3. Graph representing side effects for treatment or abuse related administration. (a) Treatment related. (b) Abuse related.

Moreover, the incidence of side effects on males was more homogeneous ( $37 \%$ endocrine disorders, $16 \%$ cardiovascular disorders, $13 \%$ skin disorders, $10 \%$ psychiatric disorders, compared to females where we found $61 \%$ endocrine disorders, $10 \%$ cardiovascular disorders, $10 \%$ skin disorders, $10 \%$ psychiatric disorders). We think this difference is due to the administration dosage and pattern. In fact, most abusers use several AAS at the same time. 


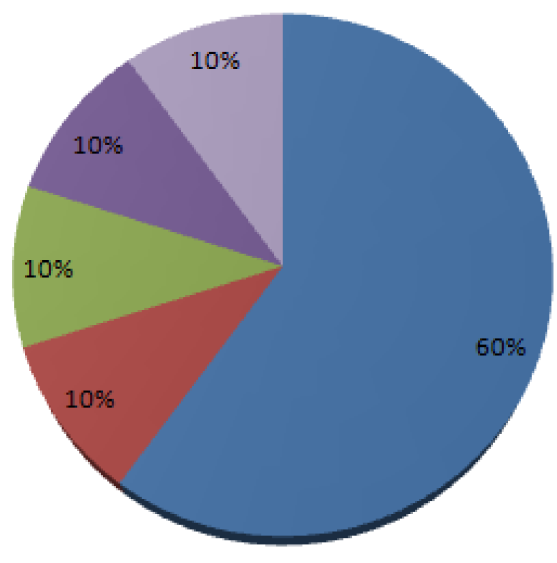

Female

(a)

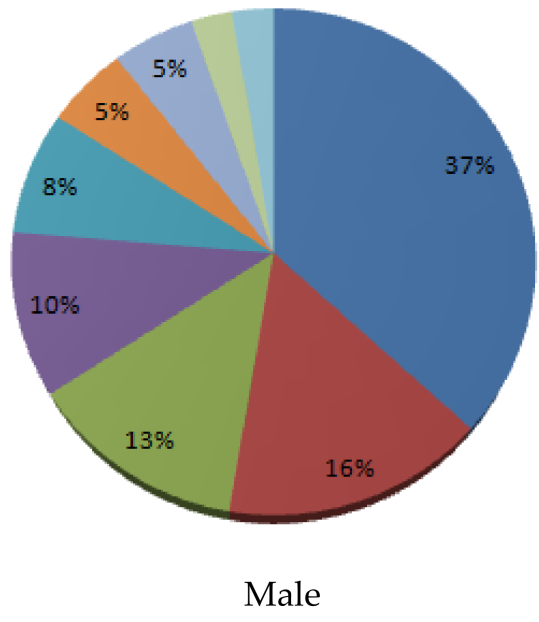

(b)

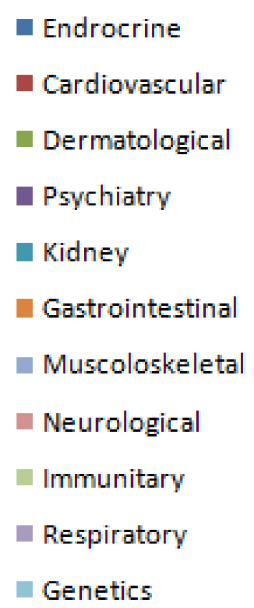

Figure 4. Graph representing side effects for males and females. (a) Females. (b) Males.

\section{Discussion}

AASs represent a large group of synthetic derivatives of testosterone designed to maximize anabolic effects (such as increasing muscle mass and strength and reducing fat) and to minimize androgenic ones (such as virilization) [30-32]. There are numerous clinically proven effects: AASs promote stimulation of growth and maturation of non-reproductive tissues and maintenance of secondary sexual characteristics and reproductive function [33]. They also promote bone growth in both young and adult populations; and have long been used as a treatment for growth delay and osteoporosis [30,34]. Anabolic androgenic steroids are clinically indicated for the treatment of chronic diseases associated with the catabolic state of the patient, in conditions of AIDS, chronic obstructive pulmonary disease, hepatic or renal failure, cancer, and in cases of burns and postsurgical recovery. They are also recommended for androgen replacement therapy after menopause, and during age-related sarcopenia [35,36].

ND is the most prescribed AAS because it exhibits the lowest incidence of adverse effects compared to beneficial effects [37]. As a result, ND had been implicated in doping, until its health risks became evident and the International Olympic Committee (IOC) abolished the use of ND in sports competitions [38]. While it is more common among so-called gym visitors, this substance is also used in criminal circles and in competitive situations where personal aggressiveness could be a determining factor.

ND is generally used in the injectable form to improve performance [23], regularly or occasionally, with a combination of multiple AASs. Athletes tend to self-administer AASs for several weeks before sports competitions believing in the synergic anabolic effects with minimal side effects and the possibility of avoiding being discovered on doping tests. [39,40].

The anabolic effect on proteins requires a specific diet necessary to maintain a correct nitrogen balance. Unfortunately, hyperproteic diets are often not balanced and excessive proteins are eliminated through urine or converted into fat [39,41]. A summary of these effects is represented in Figure 5.

In order to investigate the side effects of such abusive administration of ND, we reviewed the literature and studied the results systematically. 


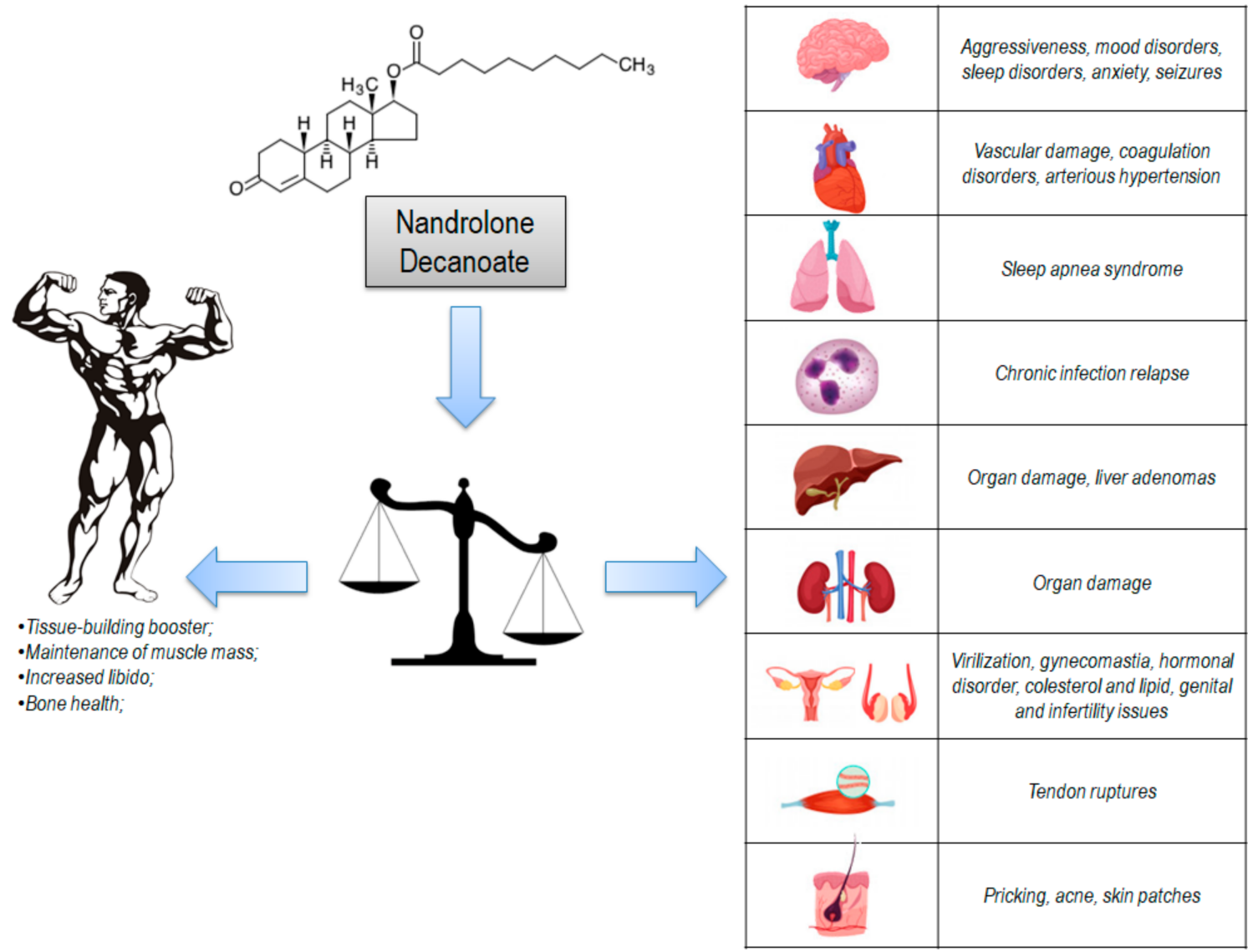

Figure 5. Where is the balance between known positive effects and underestimated or unknown side effects? This image tries to summarize this concept, because nandrolone decanoate is a molecule that affects several systems at the same time and sometimes in an irreversible way.

\subsection{Endocrine and Genital Disorders}

In our data, the most reported endocrine disorders were serum lipid alteration and virilization (for example, gynecomastia, voice pitch alteration). Several authors, after a period of administration of AASs, highlighted a significant increase of low-density lipoprotein (LDL) and decreasing high-density lipoprotein (HDL). Such effects and reversibility are dependent on dosage and treatment duration $[30,42,43]$. It has been shown that high doses of AASs induce adverse effects by increasing plasma triglyceride levels and decreasing plasma HDL-C levels up to 70\%, considered to provide anti-atherosclerotic protection [44], while some studies showed contradictory results about this aspect $[45,46]$.

ND has important effects on the hypothalamic — pituitary—adrenal Axis (HPAA) and on lipid metabolism. In a study by Gårevik et al., cholesterol level, steroid synthesizing enzymes in the adrenal gland (HMGCR) mRNA and Apo-lipoprotein B (ApoB) appeared to increase after a single dose of ND in humans, and this effect was persistent after 14 days [47]. Belgoma and colleagues [48] highlighted the molecular mechanism behind serum lipid alteration, with a downregulation of several intracellular factors that leads to the synthesis of sphingolipids and glycerolipids. AASs decrease lipogenesis by the downregulation of the activity of the lipogenic liver $\mathrm{X}$ receptor pathway via activation of the androgen receptor. Moreover, the androgen receptor induces de novo synthesis of fatty acids and cholesterol by upregulated HMG-CoA (steroid synthesizing enzymes in the adrenal gland-Coenzyme A) reductase and low-density lipoprotein (LDL) receptor.

Racca and colleagues [49], after having administered ND to rats, noted an increase in adrenocorticotrophin (ACTH) (both in blood and in pituitary corticotropes), glucocorticoid receptor (GR) 
reduction in the hippocampus and hypothalamus cytosol, and GR translocation in the hippocampus nuclear fraction, stimulation of cortical serotonin re-uptake and activation of hippocampus cytosolic extracellular signal-regulated kinases 2 (ERK2). Alsio and coworkers [50] noted an important reduction in corticosterone (CORT) plasma levels in the rat after ND treatment for 14 days; Nandrolone treatment increased HMGCR expression in the adrenal glands and reduced expression levels of the b3-adrenoceptor in adipose tissue [51].

Cases of women with ovarian follicles maturation failure, uterus, clitoris, vagina, and mammary gland hypertrophy, with hormonal disorders, confirmed by experiments on animals, have been reported in the literature. ND decreased the serum level of follicle-stimulating hormone (FSH), Luteinizing hormone (LH), progesterone and estrogen [52]. ND also promoted histological alterations in female genital organs in a dose-independent manner, despite recovery from treatment [33,53].

Virilization in female users is a well-known side effect, characterized by voice pitch alteration, body hair growth, hair loss, thick and greasy skin, acne, as well as increased libido and clitoris hypertrophy [54].

AASs also affect the activity of the sexual hormone in males, causing the inhibition of reproductive function, since the first administration [47], by turning off physiological testosterone production, causing testis atrophy, spermatogenesis inhibition (also leading to aspermia), and erectile dysfunction. They also cause biochemical modifications of prostatic secretion and seminal liquid. Most of these degenerative changes are partially reversible after treatment suspension $[33,55,56]$.

ND, among other AASs, exerts a strong negative feedback on the hypothalamic-pituitary-gonadal axis that reduces the levels of LH and FSH and leads to a reduction of testosterone. Due to the decrease in FSH levels, the growth and development of Sertoli cells is insufficient [56].

\subsection{Cardiovascular Disorders}

The effects of androgens on the cardiovascular system involve blood vessel disorders, increased erythropoiesis, hematocrit increase, hyperviscosity and hypertension, but may have direct effects on cardiac muscle and its function, decreasing potential duration, altering repolarization, and peak shortening times $[57,58]$.

In our data, the most reported cardiovascular disorders were platelet aggregation disorders and cardiac injuries. Shirpoor and coauthors [59], through experiments on rats, showed the molecular mechanisms underlying heart hypertrophy: chronic nandrolone treatment with or without strenuous exercise causes a shift in the alpha and beta-myosin heavy chain ( $\alpha$-MHC/ $\beta-\mathrm{MHC}$ ) isoform expression manifested by elevation of $\beta-\mathrm{MHC} \mathrm{mRNA}$ and the ratio of $\beta-\mathrm{MHC} \mathrm{mRNA} / \alpha-\mathrm{MHC}$ mRNA expression, as well as an increase in the heart tissue of mono-amine oxidase (MAO) and calcium/calmodulin-dependent protein kinase II- $\delta$ activities (CaMKII- $\delta$ ). Moreover, androgens have receptors in the heart and their action directly affects it through coupling directly with nuclear receptors and increasing the expression of mRNA, thus stimulating cardiac protein synthesis resulting in myocardial hypertrophy $[60,61]$.

Franquni and coauthors [62] showed the presence of cardiac remodeling and subsequent cardiac injury as indicated by the reduction in cardiac troponin I. Additionally, a reduction in the Bezold-Jarisch reflex $(\mathrm{BJR})$ control of heart rate $(\mathrm{HR})$ and blood pressure was also demonstrated. As a result of these changes, animals treated with ND demonstrated increased blood pressure that reached hypertensive levels. These mechanisms are related to the ability of ND to produce a reduction of the anti-inflammatory cytokine (IL-10) and augmentation of the pro-inflammatory cytokines (IL-6 and TNF-a) causing cardiac remodeling and injury [63-66].

In a study by Omar and colleagues, the authors suggested a mechanism of androgenic stimulation of platelet aggregation through either increased production of thromboxane A2 or decreased prostacyclin and cyclooxygenase activity, synergistic with polycythemia, and increased platelet count thus causing increased blood viscosity [67]. Pro-aggregatory effects on platelets because of high dosages of androgens could be related to a decrease in cycloxygenase activity [68]. Most of these alterations could lead to an increased thrombosis risk or atherosclerotic effects on vessels [42,69]. 
Many studies have tried to identify a direct relationship with heart disorders by performing animal experiments and identifying autonomic dysfunction [70,71], fibrosis, hypertrophy, and myopathy $[56,72,73]$, affecting ionic balance across the organ with a probable synergistic effect with other drugs [74].

Almaiman and colleagues showed an increase in creatine kinase (CKL) and creatine kinase muscle and brain subunits (CK-MB) [30]. In a case reported by Huie and coworkers, an acute myocardial infarction in an anabolic steroid user, raised questions about any link between them [75].

Most AAS abusers tend to use multiple substances at once, causing synergic effects and systemic disorders whose causes cannot be quickly identified by physicians. In a study by Clark and colleagues, the authors reported a case of a subject using several drugs, thus causing dilated cardiomyopathy [76].

Several molecular pathways are implied in androgen-induced cardiac damage, where nuclear and cytoplasmatic factors play a role [77]. ND abnormally affects ionic balance in several ways, including altered $\mathrm{Ca}^{2+}$ mobilization [74] downregulated $\mathrm{K}^{+}$channel-interacting proteins causing longer QT repolarization time [78], along with increased oxidative stress and pro-apoptotic effects [79].

Although previous studies verified the association between AAS exposure and high blood pressure, the molecular mechanisms involved in blood pressure increase due to AASs are not fully understood. Some studies, however, have suggested that mechanisms such as changes in sodium balance, degenerative vascular lesions, cardiac hypertrophy, and an unfavorable lipid profile exist $[80,81]$. Franquni M. and colleagues showed that myocyte hypertrophy and cardiac remodeling (ND related) are related to augmentation of ACE activity and the development of a pro-inflammatory state, and consequent cardiac changes result in the development of hypertension in animals treated with ND [62].

\subsection{Skin Disorders}

In our data, the most reported skin lesions were colored patches, acne, and itch disorders. Almaiman and colleagues, in a study conducted on a group of gym athletes who were using a mix of several AASs, reported itching and the emergence of skin patches among other adverse reactions [30]. Similar skin characteristics were highlighted in another case report by Tripathi and colleagues, of a 55-year-old woman [82]. Self-injection of ND in external genitalia was reported as the cause of a paraffinoma and an above skin ulceration by Balighia and colleagues, in a 56-year-old man [83]. Such findings are in line with previous literature findings [19].

\subsection{Psychiatric and Neurological Disorders}

Evidence indicates the potential role of AASs in modifying behavior with symptoms such as anxiety [84], concentration defects, irritability, and even violence during a long-term administration. In contrast, when the administration was stopped, the reported side effects were melancholy and depression $[82,85,86]$.

Aggressiveness is a common finding in AAS abusers, among other psychiatric disorders [87], and this has been confirmed by several studies on animals [88-93].

Several studies on animals confirmed neurotoxic effects of AASs in the brain. Turillazzi and colleagues demonstrated the role played by oxidative stress, thus causing an apoptotic response in the rat brain after chronic treatment with nandrolone decanoate [94]. Chronic exposure permanently influences the expression of serotonergic and noradrenergic neurotransmission [95].

Both human and animal studies have shown dysfunction of visual-spatial memory after AAS use. Magnusson and colleagues propose that administration of nandrolone to male rats may affect memory function via dynorphinergic actions [96,97].

Seitz and colleagues highlighted an increased amygdala volume and reduced resting-state functional magnetic resonance imaging (MRI) coupling of the amygdala with cognitive control and memory regions in AAS abusers. The authors concluded that long-term AAS use might alter amygdala-related functional and structural brain networks $[85,98]$. 
Moreover, Selakovic and colleagues suggested the possibility that alterations in hippocampal parvalbumin interneurons (i.e., GABAergic system) may be involved in anxiousness induced by ND abuse [99].

Chronic treatment with ND has been associated with impact on both opioid concentrations and tachykinin levels in brain areas connected with the control of emotional behavior such as depression, aggression, and reward.

The androgen action is related to its ability to bind and activate AR. The immunoreactivity of substance $\mathrm{P}(\mathrm{SP})$, which is a peptidergic factor associated with enhanced aggression in several brain regions, namely the amygdala, hypothalamus, periaqueductal gray area, and striatum [100], has been shown to increase after ND administration. ND has also been shown to react on the Substance $\mathrm{P}$ system at several levels, including receptor densities, peptide concentrations, and enzymatic processing [101,102].

ND may induce its effect directly through AR, causing oxidative stress and different effects across the brain [103]. Moreover, serotonin, glutamate, and dopamine systems, activation of gamma-aminobutyric acid (GABA) and N-methyl-D-aspartate (NMDA) receptors as well as the activation of steroid receptors, such as estrogen, mineralocorticoid, progesterone, and glucocorticoid receptors, could all contribute to the altered behaviors described. Increased aggressive behavior has been shown in many studies but there is no univocal opinion of authors because of different methodological approaches [90]. While several studies correlate severity and duration of symptoms with chronic ND administration, it is already known that a single injection of ND is enough to alter brain activity: a hyper-adrenergic state with an increased amount of 5-hydroxytryptamine (5-HT) metabolites in the hypothalamus, after a single dose [17], altered the reward system by affecting dopamine metabolism [104], and altered monoamine metabolism [105].

\subsection{Musculoskeletal Disorders}

In our collected data, we identified only two studies that reported adverse effects of ND, both concerning abusers.

Liow and colleagues reported a case of a 29-year-old male who abused a mix of several AASs and got a bilateral rupture of the quadriceps tendons [106], while Stennard and colleagues presented a case of isolated rupture of the triceps tendon in an athlete who was lifting weights [107]. Both cases suggest that oral steroid abuse may cause negative effects on the mechanical properties of connective tissue, confirming the experimental study of Marqueti and colleagues [108]. In animal experiments, anabolic steroids produced a stiffer tendon that absorbs less energy and fails with less elongation [109].

The molecular mechanism underlying this altered tendon activity may be related to collagen synthesis [60,110]. Hassager and colleagues concluded that anabolic steroids stimulate type III collagen synthesis, which affects muscular tissues as well as bone tissues [111].

\subsection{Excretory and Liver Disorders}

Hepatotoxicity is one of the most frequent side effects of AAS abuse [112,113]. AAS-induced hepatotoxicity has been hypothesized to be related to oxidative stress in hepatic cells. Indeed, because of AR activation an increase in reactive oxygen species can be observed due to the increase in mitochondrial b-oxidation. Moreover, antioxidant substances have a protective role against hepatotoxicity mediated by AASs. It has also been demonstrated that androgenic potency and metabolic resistance are positively linked to the degree of liver damage. 
AAS-induced hepatotoxicity is influenced by genetic factors and is related to the infiltration of inflammatory cells in liver tissue, such as lymphocytes, neutrophils, and eosinophils. Oxidative stress could play a role in determining liver damage consequently to AAS abuse by activating androgen receptors that lead to mitochondrial degeneration of hepatic cells. A recent study evaluated the liver effects of five weeks of ND administration in rats. The results highlighted an increase of plasma levels of liver necrosis markers, an increase in collagen deposition in liver parenchyma, portal space, and centro lobular vein $[113,114]$. The mechanism involved in collagen deposition could be the increase in the number and in the activity of Kuppfer cells. In this regard, Kuppfer cell activation leads to the production of many inflammatory cytokines, such as transforming growth factor beta 1 (TGF-b1), nuclear factor kappa-light-chain-enhancer of activated B cells (NF-Kb), and interleukin 1 beta (IL-1 $\beta$ ), related to the liver fibrosis process $[115,116]$.

Many AASs can be administrated in parenteral or oral ways, causing different metabolism altering androgenic or anabolic effects. ND is injected intramuscularly with an oil that delays absorption and is not hepatotoxic [16,117].

Several studies highlighted that prolonged androgen exposure has a direct toxic effect on kidneys, especially glomerular cells, causing the accumulation of mesangial matrix, podocyte depletion and structural adaptations [118,119]. In this regard, kidney tissues are characterized by the expression of ARs. AR activation leads to cell growth and hypertrophy in the kidney. A recent report suggested that ND exposure promotes hypertrophy in proximal and distal convoluted tubules of mice kidneys [120]. Moreover, both testosterone activity and ND direct action to AR may play a role in the genesis of kidney fibrosis after long-term ND exposure [121].

Prolonged ND administration in mice has been shown to cause dose-dependent oxidative kidney stress and damage. Indeed, mice kidneys treated with ND exhibited increased lipid peroxidation and decreased antioxidant enzymes activity, such as glutathione reductase and glutathione peroxidase. A recent study suggested a dose related oxidative stress in mice kidneys treated with prolonged doses of ND [118]. The authors observed an increase in markers of lipid peroxidation and an increase of pro-inflammatory and pro-apoptotic markers, such as IL-1 $\beta$, heat shock protein 90 (Hsp90), and tumor necrosis factor (TNF) associated with a decrease of antioxidant enzymes, which could lead to secondary focal segmental glomeruloscelerosis [118].

Bagchus and colleagues, studied healthy men after injecting ND: urinary metabolites were detectable for at least 33 days after injection and the serum concentration of ND showed a half-life of 7-12 days [38].

Increasing bilirubin, alkaline phosphatase, and transaminases are the most frequent evidence in blood. Several studies evidence the role of ND in functional and morphological liver and kidney changes, thus developing an increase of creatinine, urea, alanine transaminase and aspartate transaminase blood levels [30,122].

Kidney and liver histological changes in ND users are usually fibrosis and cell proliferation. The causes of this degenerative process are multifactorial, but much evidence shows that oxidative stress is involved $[19,60,110,111,118]$. During ultrasound examination, kidneys usually show increased volume and cortical thickness in bodybuilders who regularly take anabolic steroids. These findings are in line with the theory of a multifactorial association of steroid, hyperproteic diets and intensive sport training being involved in renal damage [94,123] along with hypertension and fluid retention that could probably be associated with a decreased level of kidney $\alpha 1 B$-adrenoceptors [124,125].

Long administration could cause hepatic peliosis, fibrosis and hepatic cancer [126], and related alteration of cellular redox balance [111,115]. Wen-Lung and colleagues studied the role of AR on different liver diseases, but univocal results have not yet been obtained. Moreover, the underlying molecular mechanism is not well defined [127]. 


\subsection{Immune Disorders}

In our collected data, we identified only one case concerning adverse effects of ND on abusers, reported by Singh and colleagues, namely a 21-year-old man who started with a mix of anabolic steroids, with the emergence of a rare serious adverse effect of suspected tubercular reactivation [46,128].

Supra-physiologic doses of common AASs alter immune function by influencing the production of certain cytokines. In fact, the users of AASs have abnormal immunoglobulin (Ig) concentrations; the lowest levels of immunoglobulin G (IgG), immunoglobulin M (IgM) and immunoglobulin A (IgA), "significantly lower" than controls for IgA and IgM [129]. Kanda and coauthors [130] showed that spontaneous IgM and IgG production in humans was inhibited by exposure to $1 \mathrm{nM}$ testosterone, which is nearly a physiological dose, suggesting that high doses would potentially adversely affect the immune system. Some studies suggest that AASs are immune suppressive and depend on the type of AAS used and the dose and timing of administration.

AASs increase serum hemoglobin concentrations, improving the aerobic capacity in athletes: two studies recorded an AAS-induced alteration of hematology in athletes [131,132]. Alen demonstrated an increase in serum hemoglobin concentration and hematocrit, platelets, and white blood cell count after six months of high dose AASs. Similarly, Hartgens and coworkers found an increase in platelet count after short-term dosing (eight weeks) of AASs. The significance of these studies is that they indicate that AAS abuse can potentially affect erythropoiesis and other hematological parameters.

Hughes and associates [133] determined that supraphysiologic doses of nandrolone decanoate and oxymethenelone enhanced the production of the inflammatory cytokines IL-1 $\beta$ and TNF- $\alpha$ in human peripheral blood lymphocyte cultures in vitro.

On this basis, it can be hypothesized that the chronic administration of nandrolone, favoring the persistence and viability of stem cells in different tissues, could represent a preconditioning that, in addition to multiple hits, could enhance the risk of carcinogenesis onset especially in stem-cell-rich tissues such as liver [40]. The side effects on the natural synthesis of anabolic steroids play a potential role on hormonal changes/regulation and they could be suspected to be at the base of certain carcinogenic mechanisms [134,135]. Furthermore, easily accessible and commonly diffused AASs, such as nandrolone and stanozolol, playa potential role in the pathogenesis of cancer, such as Leydig cell tumor, through multiple process pathways [134]. Nandrolone magnified cyclin D1 concentration, inducing breast cell proliferation. These processes, individually or in combination, can induce micronuclei formation that are strictly related to several mutagenic stresses and are formed following chromosomal damage eliciting profound modifications in genetic sequences by means of alterations in telomerase activity [136].

Nandrolone is an androgen receptor agonist. On binding to the AR, it may induce the release of the AR receptor from Hsp90 and its translocation to the nucleus; higher nandrolone concentrations induced a more pronounced increase in Hsp90 levels of expression and phosphorylation. This result is an indirect demonstration that nandrolone binds to AR and induces its activation. Hsp 90 was found to be overexpressed in multiple cancers, including prostate cancer [137].

\section{Conclusions}

The anabolic-androgenic steroids are a family of hormones abused by athletes because of their well-known properties on increasing muscle mass and strength, and among them ND is the most used one. Historically, it was used for the treatment of anemia of chronic kidney disease, or osteoporosis in postmenopausal women.

This review evidences that improper usage and abuse of AASs cause several adverse effects in all body tissues and organs, highlighting the mechanics behind side effects. To sum up, inflammatory cytokines, oxidative stress, protein synthesis alteration, and apoptosis are common mechanisms involved in AAS-related damage.

Several studies showed cardiovascular and endocrine system, reproductive system, musculoskeletal system, as well as kidney and liver are affected by side effects in most cases. To date 
most experimental studies have been conducted on animal models, because it would be unethical to administer high doses of AASs over prolonged periods of time. Much remains to be investigated about the basic mechanisms in humans. Moreover, the habit of polydrug abuse makes it hardly possible to distinguish the toxic effects of AASs from those caused by other drugs [138]. In addition, a general limitation of human studies is the fact that data about the modality and doses of AAS use/abuse are often self-reported. Furthermore, there is a tendency to abuse multiple substances at the same time. Lastly, the susceptibility of individuals is influenced by genetic factors that are well known as key factors in developing adverse events [139].

In a systematic review of the literature on online resources, we found a total of 766 articles, but only 33 studies reported data about subjects abusing ND. Most reported adverse effects were endocrine (18 studies, $42 \%$ ), cardiovascular (six studies, $14 \%$ ), skin (five studies, $12 \%$ ), and psychiatric (four studies, $9 \%$ ) disorders.

Side effects secondary to the use of ND may arise in some cases since the first administration. Some side effects regress quickly after suspension (for example, side effects on the skin or blood changes). However, there are some side effects that persist for some time and may not regress completely on suspension (for example, side effects on the reproductive, hormonal, nervous, and immune systems, organ damage to the kidney and liver, and cardiovascular or behavioral changes).

The result of this review highlights the need to investigate the consequences of the use of these substances because, currently, there are discordant results in many studies.

Author Contributions: Conceptualization, A.N.M.M., F.G.P. and A.M.; methodology, F.G.P. and A.M.; software, F.G.P.; validation, N.D.N., A.L. and G.L.R.; formal analysis, P.M., M.E., G.L.R. and G.C.; resources, F.A., A.M. and D.C.; data curation, A.N.M.M., F.G.P. and A.M.; writing-original draft preparation, F.G.P. and A.N.M.M., writing-review and editing, A.L., P.M. and M.E.; visualization, F.A. and G.C.; supervision, G.L.R., A.M. and N.D.N.; project administration, A.M., N.D.N. and G.L.R. All authors have read and agreed to the published version of the manuscript.

Funding: This research received no external funding.

Acknowledgments: The authors thank the Scientific Bureau of the University of Catania for language support.

Conflicts of Interest: The authors declare no conflict of interest. 


\section{Appendix A. General Data Obtained by Analyzing the Studies Included in This Literature Review}

\begin{tabular}{|c|c|c|c|c|c|c|c|}
\hline Name & Authors & Publication Date & Males & Females & Age & Abuse & Adverse Effects \\
\hline $\begin{array}{l}\text { Suspected reactivation of extrapulmonary tuberculosis focus after } \\
\text { non-medical abuse of anabolic androgenic steroids: a case report }\end{array}$ & Singh V, Batta A. & 2019 & 1 & 0 & 21 & Yes & Immune system disorders \\
\hline $\begin{array}{l}\text { Side effects of anabolic steroids used by athletes at Unaizah Gyms, Saudi } \\
\text { Arabia: a pilot study }\end{array}$ & Almaiman AA & 2019 & 12 & 0 & 30 & Yes & Kidney injuries, Skin disorders \\
\hline $\begin{array}{l}\text { Evaluation of anabolic steroid induced renal damage with sonography in } \\
\text { bodybuilders }\end{array}$ & Kantarci UH & 2018 & 22 & 0 & 25 & Yes & $\begin{array}{l}\text { Kidney injuries, Cardiovascular } \\
\text { disorders }\end{array}$ \\
\hline $\begin{array}{l}\text { Anabolic steroid abuse: what shall it profit a man to gain muscle and } \\
\text { suffer the loss of his brain? }\end{array}$ & Chowdhury P & 2017 & 1 & 0 & 30 & Yes & $\begin{array}{l}\text { Cardiovascular disorders, } \\
\text { Neurological disorders }\end{array}$ \\
\hline $\begin{array}{l}\text { Impact of single-dose nandrolone decanoate on gonadotropins, blood } \\
\text { lipids and HMG CoA reductase in healthy men }\end{array}$ & $\begin{array}{l}\text { Gårevik N, Börijesson A, Choong E, } \\
\text { Ekström L, Lehtihet M. }\end{array}$ & 2016 & 11 & 0 & 37,3 & No & Endocrine disorders \\
\hline $\begin{array}{l}\text { Iatrogenic dependence of anabolic-androgenic steroid in an Indian } \\
\text { non-athletic woman }\end{array}$ & $\begin{array}{l}\text { Tripathi A, Tekkalaki B, Saxena S, } \\
\text { Dandu H. }\end{array}$ & 2014 & 1 & 0 & 55 & Yes & $\begin{array}{l}\text { Psychiatric disorders, Endocrine } \\
\text { disorders, Skin disorders }\end{array}$ \\
\hline $\begin{array}{l}\text { Chromosome damage and cytotoxicity in oral mucosa cells after } 2 \\
\text { months of exposure to anabolic steroids (decadurabolin and winstrol) in } \\
\text { weight lifting }\end{array}$ & $\begin{array}{l}\text { Martins RA, Gomes GA, Aguiar O Jr, } \\
\text { Medalha CC, Ribeiro DA. }\end{array}$ & 2010 & 15 & 0 & $\begin{array}{c}\text { Not } \\
\text { available }\end{array}$ & Yes & Genetic disorders \\
\hline $\begin{array}{l}\text { Paraffinoma and ulcer of the external genitalia after self-injection of } \\
\text { nandrolone }\end{array}$ & $\begin{array}{l}\text { Balighi K, Farsinejad K, Naraghi ZS, } \\
\text { Tamizifar B. }\end{array}$ & 2008 & 1 & 0 & 56 & Yes & Skin disorders \\
\hline Acne induced by 'Sus' and 'Deca' & Walker SL, Parry EJ. & 2006 & 1 & 0 & 22 & Yes & Skin disorders \\
\hline $\begin{array}{l}\text { Dilated cardiomyopathy and acute liver injury associated with combined } \\
\text { use of ephedra, gamma-hydroxybutyrate, and anabolic steroids }\end{array}$ & Clark BM, Schofield RS. & 2005 & 1 & 0 & 40 & Yes & $\begin{array}{l}\text { Kidney injuries, Cardiovascular } \\
\text { disorders, Liver injuries, Endocrine } \\
\text { disorders }\end{array}$ \\
\hline $\begin{array}{l}\text { Hepatocellular adenomas associated with anabolic androgenic steroid } \\
\text { abuse in bodybuilders: a report of two cases and a review of the literature }\end{array}$ & $\begin{array}{l}\text { Steensland P, Blakely G, Nyberg F, } \\
\text { Fahlke C, Pohorecky LA. }\end{array}$ & 2005 & 2 & 0 & 29 & Yes & Liver injuries \\
\hline $\begin{array}{l}\text { Androgen-induced cerebral venous sinus thrombosis in a young body } \\
\text { builder: case report }\end{array}$ & $\begin{array}{l}\text { Kurling S, Kankaanp A, Ellermaa S, } \\
\text { Karila T, Sepp T. }\end{array}$ & 2004 & 1 & 0 & 22 & Yes & Cardiovascular disorders \\
\hline $\begin{array}{l}\text { Effect of Nandrolone Decanoate on serum lipoprotein (a) and its isoforms } \\
\text { in hemodialysis patients }\end{array}$ & 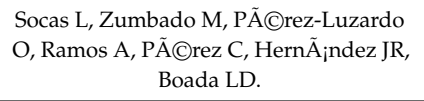 & 2004 & 47 & 17 & 63 & No & $\begin{array}{l}\text { Cardiovascular disorders, } \\
\text { Endocrine disorders }\end{array}$ \\
\hline $\begin{array}{l}\text { Effects of androgenic-anabolic steroids on apolipoproteins and } \\
\text { lipoprotein (a) }\end{array}$ & $\begin{array}{l}\text { Steensland P, Hallberg M, Kindlundh A, } \\
\text { Fahlke C, Nyberg F. } \\
\end{array}$ & 2004 & 19 & 0 & 31 & No & Endocrine disorders \\
\hline $\begin{array}{l}\text { Successful treatment of anabolic steroid-induced azoospermia with } \\
\text { human chorionic gonadotropin and human menopausal gonadotropin }\end{array}$ & Menon DK & 2003 & 1 & 0 & 37 & Yes & Endocrine disorders \\
\hline $\begin{array}{l}\text { Measurement of androgen and estrogen receptors in breast tissue from } \\
\text { subjects with anabolic steroid-dependent gynecomastia }\end{array}$ & $\begin{array}{l}\text { Calzada L, Torres-Calleja J, Martinez JM, } \\
\text { Pedron N. }\end{array}$ & 2001 & 12 & 0 & 28 & No & Endocrine disorders \\
\hline $\begin{array}{l}\text { Reversible hypogonadism and azoospermia as a result of } \\
\text { anabolic-androgenic steroid use in a bodybuilder with personality } \\
\text { disorder. A case report }\end{array}$ & $\begin{array}{l}\text { Boyadjiev NP, Georgieva KN, } \\
\text { Massaldjieva RI, Gueorguiev SI. }\end{array}$ & 2000 & 1 & 0 & 20 & Yes & $\begin{array}{l}\text { Psychiatric disorders, Endocrine } \\
\text { disorders }\end{array}$ \\
\hline Androgens for the treatment of anemia in peritoneal dialysis patients & Navarro JF & 1998 & 9 & 0 & $\begin{array}{c}\text { Not } \\
\text { available }\end{array}$ & No & Endocrine disorders \\
\hline
\end{tabular}




\begin{tabular}{|c|c|c|c|c|c|c|c|}
\hline $\begin{array}{l}\text { A report on alterations to the speaking and singing voices of four women } \\
\text { following hormonal therapy with virilizing agents }\end{array}$ & Baker J & 1999 & 0 & 4 & 43 & No & Endocrine disorders \\
\hline $\begin{array}{l}\text { Nandrolone decanoate is a good alternative for the treatment of anemia } \\
\text { in elderly male patients on hemodialysis }\end{array}$ & $\begin{array}{l}\text { Gascón A, Belvis JJ, Berisa F, Iglesias E, } \\
\text { Estopiñán V, Teruel JL. }\end{array}$ & 1999 & 14 & 0 & $\begin{array}{c}\text { Not } \\
\text { available }\end{array}$ & No & Endocrine disorders \\
\hline $\begin{array}{l}\text { Effects of nandrolone decanoate (Decadurabolin) on serum Lp(a), lipids } \\
\text { and lipoproteins in women with postmenopausal osteoporosis }\end{array}$ & $\begin{array}{l}\text { Lippi G, Guidi G, Ruzzenente O, Braga V, } \\
\text { Adami S. }\end{array}$ & 1997 & 0 & 19 & $\begin{array}{c}\text { Not } \\
\text { available }\end{array}$ & No & Endocrine disorders \\
\hline $\begin{array}{c}\text { Androgen therapy for anemia of chronic renal failure. Indications in the } \\
\text { erythropoietin era }\end{array}$ & Teruel JL & 1996 & 67 & 17 & $\begin{array}{c}\text { Not } \\
\text { available }\end{array}$ & No & Endocrine disorders \\
\hline $\begin{array}{l}\text { Exogenous androgens influence body composition and regional body fat } \\
\text { distribution in obese postmenopausal women - a clinical research } \\
\text { center study }\end{array}$ & Lovejoy JC & 1996 & 5 & 5 & $\begin{array}{c}\text { Not } \\
\text { available }\end{array}$ & No & $\begin{array}{l}\text { Psychiatric disorders, Endocrine } \\
\text { disorders, Skin disorders }\end{array}$ \\
\hline $\begin{array}{l}\text { Bilateral rupture of the quadriceps tendon associated with } \\
\text { anabolic steroids }\end{array}$ & Liow RY & 1995 & 1 & 0 & 29 & Yes & Musculoskeletal injuries \\
\hline $\begin{array}{l}\text { Assessment of attentional bias and mood in users and non-users of } \\
\text { anabolic-androgenic steroids }\end{array}$ & Bond AJ & 1995 & 32 & 0 & 23,2 & Yes & Psychiatric disorders \\
\hline An acute myocardial infarction occurring in an anabolic steroid user & Huie MJ & 1994 & 1 & 0 & $\begin{array}{c}\text { Not } \\
\text { available }\end{array}$ & Yes & Cardiovascular disorders \\
\hline $\begin{array}{l}\text { Virilization of the voice in post-menopausal women due to the anabolic } \\
\text { steroid nandrolone decanoate (Decadurabolin). The effects of medication } \\
\text { for one year }\end{array}$ & GerritsmaEJ & 1994 & 0 & 0 & $\begin{array}{c}\text { Not } \\
\text { available }\end{array}$ & No & Endocrine disorders \\
\hline Rupture of the triceps tendon associated with steroid injections & Stannard JP & 1993 & 1 & 0 & 35 & Yes & Musculoskeletal injuries \\
\hline Anabolicsteroids in postmenopausalosteoporosis & Need AG & 1993 & 0 & 0 & $\begin{array}{c}\text { Not } \\
\text { available }\end{array}$ & No & Endocrine disorders \\
\hline $\begin{array}{l}\text { Exuberant local tissue reaction to intramuscular injection of nandrolone } \\
\text { decanoate (Decadurabolin) - a steroid compound in a sesame seed oil } \\
\text { base-mimicking soft tissue malignant tumors: a case report and review } \\
\text { of the literature }\end{array}$ & Khankhanian NK & 1992 & 1 & 0 & $\begin{array}{c}\text { Not } \\
\text { available }\end{array}$ & Yes & Connective disorders \\
\hline Anabolic steroid-associated hypogonadism in male hemodialysis patients & Maeda $Y$ & 1989 & 66 & 0 & $\begin{array}{c}\text { Not } \\
\text { available }\end{array}$ & No & Endocrine disorders \\
\hline $\begin{array}{l}\text { Regeneration of murine megakaryocytopoiesis and the hematopoietic } \\
\text { inductive microenvironment after sublethal whole body irradiation by } \\
\text { treatment with an anabolic steroid }\end{array}$ & Johnson MW & 1984 & 0 & 1 & 54 & No & $\begin{array}{l}\text { Endocrine disorders, Sleep } \\
\text { Apnea Syndrome }\end{array}$ \\
\hline
\end{tabular}




\section{References}

1. Lee, D.M.; Min, T.; Choi, I.; Cheon, Y.P.; Chun, T.; Park, C.S.; Lee, K.H. Feeding effect of an anabolic steroidnandrolone, on the male rat testis. Asian-Australas J. Anim. Sci. 2010, 23, 1566-1577. [CrossRef]

2. Sessa, F.; Salerno, M.; Di Mizio, G.; Bertozzi, G.; Messina, G.; Tomaiuolo, B.; Pisanelli, D.; Maglietta, F.; Ricci, P.; Pomara, C. Anabolic Androgenic Steroids: Searching New Molecular Biomarkers. Front. Pharmacol. 2018, 9. [CrossRef] [PubMed]

3. Evans, N.A. Current Concepts in Anabolic-Androgenic Steroids. Am. J. Sports Med. 2004, 32, 534-542. [CrossRef] [PubMed]

4. Pomara, C.; Neri, M.; Bello, S.; Fiore, C.; Riezzo, I.; Turillazzi, E. Neurotoxicity by Synthetic Androgen Steroids: Oxidative Stress, Apoptosis, and Neuropathology: A Review. Curr. Neuropharmacol. 2015, 13, 132-145. [CrossRef]

5. Monda, V.; Salerno, M.; Fiorenzo, M.; Villano, I.; Viggiano, A.; Sessa, F.; Triggiani, A.I.; Cibelli, G.; Valenzano, A.; Marsala, G.; et al. Role of sex hormones in the control of vegetative and metabolicfunctions of middle-agedwomen. Europe PMC 2017, 8, 773. [CrossRef]

6. Wijnand, H.P.; Bosch, A.M.G.; Donker, C.W. Pharmacokinetic parameters of nandrolone (19-nortestosterone) after intramuscular administration of nandrolone decanoate (Deca-Durabolin ${ }^{\circledR}$ ) to healthy volunteers. Eur. J. Endocrinol. 1985, 110, S19-S30. [CrossRef]

7. Pardridge, W.M. 4 Serum bioavailability of sex steroid hormones. Clin. Endocrinol. Metab. 1986, 15, $259-278$. [CrossRef]

8. Llewellyn, W. Anabolics. Mol. Nutr. 2011, 193-194, 402-412.

9. Basaria, S.; Wahlstrom, J.T.; Dobs, A.S. Clinical review 138: Anabolic-androgenic steroid therapy in the treatment of chronic diseases. J. Clin. Endocrinol. Metab. 2001, 86, 5108-5117. [CrossRef]

10. Bahrke, M.S.; Yesalis, C.E., 3rd; Wright, J.E. Psychological andbehavioural effects of endogenous testosterone and anabolicandrogenicsteroids. Update Sports Med. 1996, 22, 367-390. [CrossRef]

11. Buckley, W.E.; Yesalis, C.E., 3rd; Friedl, K.E.; Anderson, W.A.; Streit, A.L.; Wright, J.E. Estimated prevalence of anabolic steroiduse among male high school seniors. JAMA 1988, 260, 3210283. [CrossRef]

12. DuRant, R.H.; Rickert, V.I.; Ashworth, C.S.; Newman, C.; Slavens, G. Use of multiple drugs among adolescents who useanabolic steroids. NEJM 1993, 328, 922-926. [CrossRef] [PubMed]

13. Kopera, H. The history of anabolic steroids and a review of clinicalexperience with anabolic steroids. Acta Endocrinol. Suppl. 1985, 271, 11-18. [CrossRef] [PubMed]

14. Kadi, F.; Bonnerud, P.; Eriksson, A.; Thornell, L.-E. The expression of androgen receptors in human neck and limb muscles: Effects of training and self-administration of androgenic-anabolic steroids. Histochem. Cell Biol. 2000, 113, 25-29. [CrossRef] [PubMed]

15. Sinha-Hikim, I.; Artaza, J.; Woodhouse, L.; Gonzalez-Cadavid, N.; Singh, A.B.; Lee, M.I.; Storer, T.W.; Casaburi, R.; Shen, R.; Bhasin, S. Testosterone-induced increase in muscle size in healthy young men is associated with muscle fiber hypertrophy. Am. J. Physiol. Metab. 2002, 283, E154-E164. [CrossRef]

16. Pan, M.M.; Kovac, J.R. Beyond testosterone cypionate: Evidence behind the use of nandrolone in male health and wellness. Transl. Androl. Urol. 2016, 5, 213-219. [CrossRef]

17. Tamaki, T.; Shiraishi, T.; Takeda, H.; Matsumiya, T.; Roy, R.R.; Edgerton, V.R. Nandrolone Decanoate Enhances Hypothalamic Biogenic Amines in Rats. Med. Sci. Sports Exerc. 2003, 35, 32-38. [CrossRef] [PubMed]

18. Shahidi, N.T. A review of the chemistry, biological action, and clinical applications of anabolic-androgenic steroids. Clin. Ther. 2001, 23, 1355-1390. [CrossRef]

19. Turillazzi, E.; Perilli, G.; Di Paolo, M.; Neri, M.; Riezzo, I.; Fineschi, V. Side effects of AAS abuse: An overview. Mini-Rev. Med. Chem. 2011, 11, 374-389. [CrossRef]

20. Van Amsterdam, J.; Opperhuizen, A.; Hartgens, F. Adverse health effects of anabolic-androgenic steroids. Regul. Toxicol. Pharmacol. 2010, 57, 117-123. [CrossRef]

21. Brower, K.J. Anabolic steroid abuse and dependence. Curr. Psychiatry Rep. 2002, 4, 377-387. [CrossRef] [PubMed]

22. Basaria, S. Androgen Abuse in Athletes: Detection and Consequences. J. Clin. Endocrinol. Metab. 2010, 95, 1533-1543. [CrossRef] [PubMed] 
23. Frati, P.; Busardò, F.P.; Cipolloni, L.; De Dominicis, E.; Fineschi, V. Anabolic Androgenic Steroid (AAS) Related Deaths: Autoptic, Histopathological and Toxicological Findings. Curr. Neuropharmacol. 2015, 13, 146-159. [CrossRef] [PubMed]

24. Hall, R.C. Abuse of supraphysiologic doses of anabolic steroids. South Med. J. 2005, 98, 550-555. [CrossRef] [PubMed]

25. Dotson, J.L.; Brown, R.T. The History of the Development of Anabolic-Androgenic Steroids. Pediatr. Clin. N. Am. 2007, 54, 761-769. [CrossRef]

26. Stojanovic, M.D.; Ostojic, S.M. Steroids From Physiology to Clinical Medicine; Intech: Rijeka, Croatia, 2012; pp. 169-186. [CrossRef]

27. De Souza, G.L.; Hallak, J. Anabolic steroids and male infertility: A comprehensive review. BJU Int. 2011, 108, 1860-1865. [CrossRef]

28. Fink, J.; Schoenfeld, B.J.; Hackney, A.C.; Matsumoto, M.; Maekawa, T.; Nakazato, K.; Horie, S. Anabolic-androgenic steroids: Procurement and administration practices of doping athletes. Physician Sportsmed. 2018, 47, 10-14. [CrossRef]

29. Pope, H.G.; Kanayama, G.; Ionescu-Pioggia, M.; Hudson, J.I. Anabolic steroidusers'attitudes towards physicians. Addiction 2004, 99, 1189-1194. [CrossRef]

30. Almaiman, A.A.; Almaiman, S.H.; Elagamy, E.I.; Al Wutayd, O.; Almarzuqi, M.; Alzunaidi, R.; Alhatlani, S.; Eid, E.E. Side effects of anabolicsteroidsused by athletesatUnaizahGyms, Saudi Arabia: A pilotstudy. J. Sports MedPhys. Fit. 2019, 59, 489-495. [CrossRef]

31. Sessa, F.; Salerno, M.; Bertozzi, G.; Cipolloni, L.; Messina, G.; Aromatario, M.; Polo, L.; Turillazzi, E.; Pomara, C. miRNAs as Novel Biomarkers of Chronic Kidney Injury in Anabolic-Androgenic Steroid Users: An Experimental Study. Front. Pharmacol. 2020, 11. [CrossRef]

32. Albano, G.D.; Sessa, F.; Messina, A.; Monda, V.; Bertozzi, G.; Maglietta, F.; Giugliano, P.; Vacchiano, G.; Gabriella, M.; Salerno, M. AAS and organs damage: A focus on Nandrolone effects. Oncotarget 2017, 6, 939-946.

33. Andrade, G.; Simão, V.; Souza, B.; Chuffa, L.G.A.; Camargo, I.C.C. Sex steroid receptors profiling is influenced by nandrolone decanoate in the ampulla of the fallopian tube: Post-treatment and post-recovery analyses. Tissue Cell 2018, 50, 79-88. [CrossRef] [PubMed]

34. Sessa, F.; Salerno, M.; Cipolloni, L.; Bertozzi, G.; Messina, G.; Di Mizio, G.; Asmundo, A.; Pomara, C. Anabolic-androgenic steroids and brain injury: miRNA evaluation in users compared to cocaine abusers and elderly people. Aging 2020, 12, 15314-15327. [CrossRef] [PubMed]

35. Simão, V.A.; Berloffa Belardin, L.; AraújoLeite, G.A.; de AlmeidaChuffa, L.G.; Camargo, I.C. Effects of different doses of nandrolonedecanoate on estrous cycle and ovarian tissue of rats after treatment and recovery periods. Int. J. Exp. Pathol. 2015, 96, 338-349. [CrossRef] [PubMed]

36. Bafunno, V.; Santacroce, R.; Chetta, M.; Peyvandi, F.; Sessa, F.; Chinni, E.; Longo, V.; Margaglione, M. PolymorphicmiRNA-mediated gene contribution to inhibitor development in haemophilia A. Haemophilia 2012, 18, 1003-1007. [CrossRef]

37. Gomes, F.C.; Chuffa, L.G.A.; Scarano, W.R.; Pinheiro, P.F.F.; Fávaro, W.J.; Domeniconi, R.F. Nandrolone decanoate and resistance exercise training favor the occurrence of lesions and activate the inflammatory response in the ventral prostate. Andrology 2016, 4, 473-480. [CrossRef]

38. Bagchus, W.M.; Smeets, J.M.W.; Verheul, H.A.M.; Veen, S.M.D.J.-V.D.; Port, A.; Geurts, T.B.P. Pharmacokinetic Evaluation of Three Different Intramuscular Doses of Nandrolone Decanoate: Analysis of Serum and Urine Samples in Healthy Men. J. Clin. Endocrinol. Metab. 2005, 90, 2624-2630. [CrossRef]

39. Pany, S.; Panigrahi, S.K.; Rao, E.V.; Patnaik, L.; Sahu, T. Anabolic Androgenic Steroid Abuse and their Health Impacts: A Cross-sectional Study among Body Builders in a City of Eastern India. Int. J. Prev. Med. 2019, 10, 178. [CrossRef]

40. Agriesti, F.; Tataranni, T.; Pacelli, C.; Scrima, R.; Laurenzana, I.; Ruggieri, V.; Cela, O.; Mazzoccoli, C.; Salerno, M.; Sessa, F.; et al. Nandrolone induces a stemcell-like phenotype in human hepatocarcinomaderivedcell line inhibiting mitochondrial respiratory activity. Sci. Rep. 2020, 10, 2287. [CrossRef]

41. Sessa, F.; Maglietta, F.; Bertozzi, G.; Salerno, M.; Di Mizio, G.; Messina, G.; Montana, A.; Ricci, P.; Pomara, C. Human Brain Injury and miRNAs: An Experimental Study. Int. J. Mol. Sci. 2019, 20, 1546. [CrossRef] 
42. Ghorbani-Haghjo, A.; Argani, H.; Rahbaninobar, M.; Rashtchizadeh, N. Effect of Nandrolone Decanoate on Serum Lipoprotein (a) and its isoforms in hemodialysis patients. Lipids Heal. Dis. 2004, 3, 16. [CrossRef] [PubMed]

43. Hartgens, F.; Rietjens, G.; Keizer, H.; Kuipers, H.; Wolffenbuttel, B. Effects of androgenic-anabolic steroids on apolipoproteins and lipoprotein (a). Br. J. Sports Med. 2004, 38, 253-259. [CrossRef] [PubMed]

44. Achar, S.; Rostamian, A.; Narayan, S.M. Cardiac and Metabolic Effects of Anabolic-Androgenic Steroid Abuse on Lipids, Blood Pressure, Left Ventricular Dimensions, and Rhythm. Am. J. Cardiol. 2010, 106, 893-901. [CrossRef] [PubMed]

45. Glazer, G.; Suchman, A.L. Lack of demonstrated effect of nandrolone on serum lipids. Metabolism 1994, 43, 204-210. [CrossRef]

46. Pomara, C.; Barone, R.; Gammazza, A.M.; Sangiorgi, C.; Barone, F.; Pitruzzella, A.; Locorotondo, N.; Di Gaudio, F.; Salerno, M.; Maglietta, F.; et al. Effects of Nandrolone Stimulation on Testosterone Biosynthesis in Leydig Cells. J. Cell. Physiol. 2016, 231, 1385-1391. [CrossRef]

47. Gårevik, N.; Börjesson, A.; Choong, E.; Ekström, L.; Lehtihet, M. Impact of single-dose nandrolone decanoate on gonadotropins, blood lipids and HMG CoA reductase in healthy men. Andrologia 2015, 48, 595-600. [CrossRef]

48. Balgoma, D.; Zelleroth, S.; Grönbladh, A.; Hallberg, M.; Pettersson, C.; Hedeland, M. Anabolic androgenic steroids exert a selective remodeling of the plasma lipidome that mirrors the decrease of the de novo lipogenesis in the liver. Metabolomics 2020, 16, 12-13. [CrossRef]

49. Racca, S.; Piccione, F.; Spaccamiglio, A.; Carriero, V.M.; De Francia, S.; Cangemi, L.; Esculapio, P.; Papotti, M.; Migliaretti, G.; Portaleone, P.; et al. Effects of sub-chronic nandrolone administration on hormonal adaptive response to acute stress in rats. Psychoneuroendocrinology 2012, 37, 1234-1247. [CrossRef]

50. Clark, A.S.; Henderson, L.P. Behavioral and physiological responses to anabolic-androgenic steroids. Neurosci. Biobehav. Rev. 2003, 27, 413-436. [CrossRef]

51. Nishizawa, H.; Shimomura, I.; Kishida, K.; Maeda, N.; Kuriyama, H.; Nagaretani, H.; Matsuda, M.; Kondo, H.; Furuyama, N.; Kihara, S.; et al. Androgens Decrease Plasma Adiponectin, an Insulin-Sensitizing Adipocyte-Derived Protein. Diabetes 2002, 51, 2734-2741. [CrossRef]

52. Mesbah, F.; Bordbar, H.; Talaei-Khozani, T.; Dehghani, F.; Mirkhani, H.M. The non-preventive effects of human menopausal gonadotropins on ovarian tissues in Nandrolone decanoate-treated female rats: A histochemical and ultra-structural study. Int. J. Reprod. Biomed. 2018, 16, 159-174. [CrossRef] [PubMed]

53. Chuffa, L.G.A.; De Souza, R.B.; Frei, F.; Mesquita, S.D.F.P.; Camargo, I.C.C. Nandrolone Decanoate and Physical Effort: Histological and Morphometrical Assessment in Adult Rat Uterus. Anat. Rec. Adv. Integr. Anat. Evol. Biol. 2010, 294, 335-341. [CrossRef] [PubMed]

54. Gerritsma, E.J.; Brocaar, M.P.; Hakkesteegt, M.M.; Birkenhäger, J.C. Virilization of the voice in post-menopausal women due to the anabolic steroid nandrolone decanoate (decadurabolin). the effects of medication for one year. Clin. Otolaryngol. 1994, 19, 79-84. [CrossRef] [PubMed]

55. Mohammed, E.T.; Radi, A.M.; Aleya, L.; Abdel-Daim, M.M. Cynara scolymus leaves extract alleviates nandrolone decanoate-induced alterations in testicular function and sperm quality in albino rats. Environ. Sci. Pollut. Res. 2019, 27, 5009-5017. [CrossRef]

56. Kahal, A.; Allem, R.; Zahzeh, T.; Koriche, S.; Kouri, A.; Douani, A.; Kassoul, H.; Ababou, A. Evolutions in cardiac and gonadal ultra-structure during a "cycle" of androgenic anabolic abuse in adult male mice. Steroids 2020, 155, 108571. [CrossRef]

57. Kimura, N.; Mizokami, A.; Oonuma, T.; Sasano, H.; Nagura, H. Immunocy tochemical localization of androgen receptor with polyclonal antibody in paraffin-embedded human tissues. J. Histochem. Cytochem. 1993, 41, 671-678. [CrossRef]

58. Pomara, C.; D’Errico, S.; Riezzo, I.; De Cillis, G.P.; Fineschi, V. Sudden cardiac death in a child affected by Prader-Willi syndrome. Int. J. Leg. Med. 2005, 119, 153-157. [CrossRef]

59. Shirpoor, A.; Heshmatian, B.; Tofighi, A.; Eliasabad, S.N.; Kheradmand, F.; Zerehpoosh, M. Nandrolone administration with or without strenuous exercise increases cardiac fatal genes overexpression, calcium/calmodulin-dependent protein kinaseii $\delta$, and monoamine oxidase activities and enhances blood pressure in adult wistar rats. Gene 2019, 697, 131-137. [CrossRef]

60. Liu, P.Y.; Death, A.K.; Handelsman, D.J. Androgens and Cardiovascular Disease. Endocr. Rev. 2003, 24, 313-340. [CrossRef] 
61. Melchert, R.B.; Welder, A.A. Cardiovascular effects of androgenic-anabolic steroids. Med. Sci. Sports Exerc. 1995, 27, 1252-1262. [CrossRef]

62. Franquni, J.V.M.; Nascimento, A.M.D.; Lima, E.M.; Brasil, G.A.; Heringer, O.A.; Cassaro, K.O.D.S.; Da Cunha, T.V.P.; Musso, C.; Santos, M.C.L.S.; Kalil, I.C.; et al. Nandrolone decanoate determines cardiac remodelling and injury by an imbalance in cardiac inflammatory cytokines and ACE activity, blunting of the Bezold-Jarisch reflex, resulting in the development of hypertension. Steroids 2013, 78, 379-385. [CrossRef]

63. Wei, P.K.M. Cytokine responses and myocardial injury in coronary artery bypass grafting. Scand. J. Clin. Lab. Investig. 2001, 61, 161-166. [CrossRef]

64. Carmo, E.C.D.; Fernandes, T.; Koike, D.; Da Silva, N.D.; Mattos, K.C.; Rosa, K.T.; Barretti, D.; Melo, S.F.S.; Wichi, R.B.; Irigoyen, M.C.C.; et al. Anabolic Steroid Associated to Physical Training Induces Deleterious Cardiac Effects. Med. Sci. Sports Exerc. 2011, 43, 1836-1848. [CrossRef] [PubMed]

65. Du Toit, E.F.; Rossouw, E.; Van Rooyen, J.; Lochner, A. Proposed mechanisms for theanabolic steroid-induced increase in myocardial susceptibility to ischaemia/reperfusion injury. Cardiovasc. J. S. Afr. 2005, 16, 21-28. [PubMed]

66. Tanno, A.P.; Das Neves, V.J.; Rosa, K.T.; Cunha, T.S.; Giordano, F.C.L.; Calil, C.M.; Guzzoni, V.; Fernandes, T.; Oliveira, E.M.; Novaes, P.D.; et al. Nandrolone and resistance training induce heart remodeling: Role of fetal genes and implications for cardiac pathophysiology. Life Sci. 2011, 89, 631-637. [CrossRef] [PubMed]

67. Omar, M.; Abdul, R.; Panday, A.; Teelucksingh, S. Anabolic steroid abuse: What shall it profit a man to gain muscle and suffer the loss of his brain? QJM: Int. J. Med. 2017, 110, 747-748. [CrossRef]

68. Sahraian, M.A.; Mottamedi, M.; Saeen, A.A.; Moghimi, B. Androgen-induced cerebral venous sinus thrombosis in a young body builder: Case report. BMC Neurol. 2004, 4, 22. [CrossRef] [PubMed]

69. Neri, M.; Riezzo, I.; Pomara, C.; Schiavone, S.; Turillazzi, E. Oxidative-Nitrosative Stress and Myocardial Dysfunctions in Sepsis: Evidence from the Literature and Postmortem Observations. Mediat. Inflamm. 2016, 2016, 1-12. [CrossRef] [PubMed]

70. Marocolo, M.; Silva-Neto, J.A.; Neto, O.B. Acute interruption of treatment with nandrolone decanoate is not sufficient to reverse cardiac autonomic dysfunction and ventricular repolarization disturbances in rats. Steroids 2018, 132, 12-17. [CrossRef] [PubMed]

71. Phillis, B.D.; Abeywardena, M.Y.; Adams, M.J.; Kennedy, J.A.; Irvine, R.J. Nandrolone Potentiates Arrhythmogenic Effects of Cardiac Ischemia in the Rat. Toxicol. Sci. 2007, 99, 605-611. [CrossRef]

72. Akbari, Z.; Esmailidehaj, M.; Avarand, E.; Shariati, M.; Pourkhalili, K. Ischemic Preconditioning Efficacy Following Anabolic Steroid Usage: A Clear Difference Between Sedentary and Exercise-Trained Rat Hearts. Cardiovasc. Toxicol. 2018, 19, 287-296. [CrossRef] [PubMed]

73. Vasilaki, F.; Tsitsimpikou, C.; Tsarouhas, K.; Germanakis, I.; Tzardi, M.; Kavvalakis, M.; Ozcagli, E.; Kouretas, D.; Tsatsakis, A.M. Cardiotoxicity in rabbits after long-term nandrolone decanoate administration. Toxicol. Lett. 2016, 241, 143-151. [CrossRef] [PubMed]

74. Seara, F.D.A.C.; Arantes, P.C.; Domingos, A.E.; Barbosa, R.A.; Olivares, E.L.; Sudo, R.T.; De Carvalho, A.C.C.; Nascimento, J.H. Cardiac electrical and contractile disorders promoted by anabolic steroid overdose are associated with late autonomic imbalance and impaired $\mathrm{Ca}^{2+}$ handling. Steroids 2019, 148, 1-10. [CrossRef] [PubMed]

75. Huie, M.J. An acute myocardial infarction occurring in an anabolic steroid user. Med. Sci. Sports Exerc. 1994, 26, 408-413. [CrossRef]

76. Clark, B.M.; Schofield, R.S. Dilated Cardiomyopathy and Acute Liver Injury Associated with Combined Use of Ephedra, $\gamma$-Hydroxybutyrate, and Anabolic Steroids. Pharmacother. J. Hum. Pharmacol. Drug Ther. 2005, 25, 756-761. [CrossRef]

77. Lucas-Herald, A.K.; Alves-Lopes, R.; Montezano, A.C.; Ahmed, S.F.; Touyz, R.M. Genomic and non-genomic effects of androgens in the cardiovascular system: Clinical implications. Clin. Sci. 2017, 131, 1405-1418. [CrossRef]

78. Medei, E.; Marocolo, M.; Rodrigues, D.D.C.; Arantes, P.C.; Takiya, C.M.; Silva, J.; Rondinelli, E.; Goldenberg, R.C.D.S.; De Carvalho, A.C.C.; Nascimento, J.H.M. Chronic treatment with anabolic steroids induces ventricular repolarization disturbances: Cellular, ionic and molecular mechanism. J. Mol. Cell. Cardiol. 2010, 49, 165-175. [CrossRef] 
79. Fanton, L.; Belhani, D.; Vaillant, F.; Tabib, A.; Gomez, L.; Descotes, J.; Dehina, L.; Bui-Xuan, B.; Malicier, D.; Timour, Q. Heart lesions associated with anabolic steroid abuse: Comparison of post-mortem findings in athletes and norethandrolone-induced lesions in rabbits. Exp. Toxicol. Pathol. 2009, 61, 317-323. [CrossRef]

80. Guzzoni, V.; Cunha, T.S.; Das Neves, V.J.; Briet, L.; Costa, R.; Moura, M.J.C.S.; Oliveira, V.; Franco, M.; Novaes, P.D.; Marcondes, F.K. Nandrolone combined with strenuous resistance training reduces vascular nitric oxide bioavailability and impairs endothelium-dependent vasodilation. Steroids 2018, 131, 7-13. [CrossRef]

81. Tofighi, A. The effect of nandrolone treatment with and without enforced swimming on histological and biochemical changes in the heart and coronary artery of male rats. Anatol. J. Cardiol. 2017, 17, 176-183. [CrossRef]

82. Tripathi, A.; Tekkalaki, B.; Saxena, S.; Himanshu, D. Iatrogenic dependence of anabolic-androgenic steroid in an Indian non-athletic woman. BMJ Case Rep. 2014, 2014, 2013202472. [CrossRef] [PubMed]

83. Balighi, K.; Farsinejad, K.; Naraghi, Z.S.; Tamizifar, B. Paraffinoma and ulcer of the external genitalia after self-injection of nandrolone. Int. J. Dermatol. 2008, 47, 1092-1094. [CrossRef] [PubMed]

84. Rosic, G.; Joksimovic, J.; Selakovic, D.; Milovanovic, D.; Jakovljevic, V. Anxiogenic effects of chronic exposure to nandrolone decanoate (ND) atsupraphysiological dose in rats: A brief report. Neuro EndocrinolLett. 2014, 35, 703-710.

85. Seitz, J.; Lyall, A.E.; Kanayama, G.; Makris, N.; Hudson, J.I.; Kubicki, M.; Kaufman, M.J. White matterabnormalities in long-term anabolic-androgenic steroidusers: A pilotstudy. Psychiatry Res. Neuroimaging 2017, 260, 1-5. [CrossRef]

86. Thurelius, A.-M.; Garle, M.; Rane, A. The anti-doping hot-line, a means to capture the abuse of doping agents in the Swedish society and a new service function in clinical pharmacology. Eur. J. Clin. Pharmacol. 2003, 59, 571-577. [CrossRef]

87. Boyadjiev, N.P.; Georgieva, K.N.; Massaldjieva, R.I.; Gueorguiev, S.I. Reversible hypogonadism and azoospermia as a result of anabolic-androgenic steroid use in a bodybuilder with personality disorder. A case report. J. Sports Med. Phys. Fit. 2000, 40, 271.

88. Masonis, A.; McCarthy, M.P. Direct interactions of androgenic/anabolic steroids with the peripheral benzodiazepine receptor in rat brain: Implications for the psychological and physiological manifestations of androgenic/anabolic steroid abuse. J. Steroid Biochem. Mol. Biol. 1996, 58, 551-555. [CrossRef]

89. Bertozzi, G.; Salerno, M.; Pomara, C.; Sessa, F. Neuropsychiatric and Behavioral Involvement in AAS Abusers. A Literature Review. Medicina 2019, 55, 396. [CrossRef]

90. Busardò, F.P.; Frati, P.; Di Sanzo, M.; Napoletano, S.; Pinchi, E.; Zaami, S.; Fineschi, V. The Impact of Nandrolone Decanoate on the Central Nervous System. Curr. Neuropharmacol. 2015, 13, 122-131. [CrossRef]

91. McGinnis, M.Y.; Lumia, A.R.; Possidente, B.P. Effects of withdrawal from anabolic androgenic steroids on aggression in adult male rats. Physiol. Behav. 2002, 75, 541-549. [CrossRef]

92. Long, S.F.; Wilson, M.C.; Sufka, K.J.; Davis, W. The effects of cocaine and nandrolone co-administration on aggression in male rats. Prog. Neuro-Psychopharmacol. Biol. Psychiatry 1996, 20, 839-856. [CrossRef]

93. McGinnis, M.Y. Anabolic Androgenic Steroids and Aggression: Studies Using Animal Models. Ann. N. Y. Acad. Sci. 2006, 1036, 399-415. [CrossRef] [PubMed]

94. Turillazzi, E.; Neri, M.; Cerretani, D.; Cantatore, S.; Frati, P.; Moltoni, L.; Busardò, F.P.; Pomara, C.; Riezzo, I.; Fineschi, V. Lipid peroxidation and apoptotic response in rat brain areas induced by long-term administration of nandrolone: The mutual cross talk between ROS and NF-kB. J. Cell Mol. Med. 2016, 20, 601-612. [CrossRef] [PubMed]

95. Rainer, Q.; Speziali, S.; Rubino, T.; Dominguez-Lopez, S.; Bambico, F.R.; Gobbi, G.; Parolaro, D. Chronic nandrolone decanoate exposure during adolescence affects emotional behavior and monoaminergic neurotransmission in adulthood. Neuropharmacology 2014, 83, 79-88. [CrossRef] [PubMed]

96. Magnusson, K.; Hånell, A.; Bazov, I.; Clausen, F.; Zhou, Q.; Nyberg, F. Nandrolone decanoate administration elevates hippocampal prodynorphin mRNA expression and impairsMorris water maze performance in male rats. Neurosci. Lett. 2009, 467, 189-193. [CrossRef]

97. Bertozzi, G.; Sessa, F.; Albano, G.D.; Sani, G.; Maglietta, F.; Roshan, M.H.K.; Volti, G.L.; Bernardini, R.; Avola, R.; Pomara, C.; et al. The Role of Anabolic Androgenic Steroids in Disruption of the Physiological Function in Discrete Areas of the Central Nervous System. Mol. Neurobiol. 2018, 55, 5548-5556. [CrossRef] 
98. Monda, V.; Salerno, M.; Sessa, F.; Bernardini, R.; Valenzano, A.; Marsala, G.; Zammit, C.; Avola, R.; Carotenuto, M.; Messina, G.; et al. Functional Changes of Orexinergic Reaction to Psychoactive Substances. Mol. Neurobiol. 2018, 55, 6362-6368. [CrossRef]

99. Selakovic, D.; Joksimovic, J.; Zaletel, I.; Puskas, N.; Matovic, M.; Rosic, G. The opposite effects of nandrolone decanoate and exercise on anxiety levels in rats may involve alterations in hippocampal parvalbumin-positive interneurons. PLOS ONE 2017, 12, e0189595. [CrossRef]

100. Hallberg, M.; Johansson, P.; Kindlundh, A.M.; Nyberg, F. Anabolic-androgenic steroids affect the content of substance $P$ and substance P1-7 in the rat brain. Peptides 2000, 21, 845-852. [CrossRef]

101. Pernow, B. Distribution of Substance P in the Central and Peripheral Nervous System. Nat. Cell Biol. 1953, 171, 746. [CrossRef]

102. Chang, M.M.; Leeman, S.E.; Niall, H.D. Amino-acid Sequence of Substance P. Nat. New Biol. 1971, $232,86-87$. [CrossRef] [PubMed]

103. Zarei, F.; Moradpour, F.; Moazedi, A.A.; Pourmotabbed, A.; Veisi, M.; Veisi, M. Nandrolone administration abolishes hippocampal fEPSP-PS potentiation and passive avoidance learning of adolescent male rats. Can. J. Physiol. Pharmacol. 2019, 97, 130-139. [CrossRef] [PubMed]

104. Kurling, S.; Kankaanpää, A.; Seppälä, T. Sub-chronic nandrolone treatment modifies neurochemical and behavioral effects of amphetamine and 3,4-methylenedioxymethamphetamine (MDMA) in rats. Behav. Brain Res. 2008, 189, 191-201. [CrossRef] [PubMed]

105. Birgner, C.; Kindlundh-Högberg, A.M.; Oreland, L.; Alsiö, J.; Lindblom, J.; Schiöth, H.B.; Bergström, L. Reduced activity of monoamine oxidase in the rat brain following repeated nandrolone decanoate administration. Brain Res. 2008, 1219, 103-110. [CrossRef] [PubMed]

106. Liow, R.Y.; Tavares, S. Bilateral rupture of the quadriceps tendon associated with anabolic steroids. Br. J. Sports Med. 1995, 29, 77-79. [CrossRef] [PubMed]

107. Stannard, J.P.; Bucknell, A.L. Rupture of the triceps tendon associated with steroid injections. Am. J. Sports Med. 1993, 21, 482-485. [CrossRef] [PubMed]

108. Marqueti, R.D.C.; Prestes, J.; Wang, C.C.; Ramos, O.H.P.; Perez, S.E.A.; Nakagaki, W.R.; Carvalho, H.F.; Selistre-De-Araujo, H.S. Biomechanical responses of different rat tendons to nandrolone decanoate and load exercise. Scand. J. Med. Sci. Sports 2010, 21, e91-e99. [CrossRef]

109. Miles, J.W.; A Grana, W.; Egle, D.; Min, K.W.; Chitwood, J. The effect of anabolic steroids on the biomechanical and histological properties of rat tendon. J. Bone Jt. Surg. Am. Vol. 1992, 74, 411-422. [CrossRef]

110. Tsitsimpikou, C.; Vasilaki, F.; Tsarouhas, K.; Fragkiadaki, P.; Tzardi, M.; Goutzourelas, N.; Nepka, C.; Kalogeraki, A.; Heretis, I.; Epitropaki, Z.; et al. Nephrotoxicity in rabbits after long-term nandrolone decanoate administration. Toxicol. Lett. 2016, 259, 21-27. [CrossRef]

111. Frankenfeld, S.P.; Oliveira, L.P.; Ortenzi, V.H.; Rego-Monteiro, I.C.; Chaves, E.A.; Ferreira, A.C.; Leitão, A.C.; Carvalho, D.P.; Fortunato, R.S. The Anabolic Androgenic Steroid Nandrolone Decanoate Disrupts Redox Homeostasis in Liver, Heart and Kidney of Male Wistar Rats. PLoS ONE 2014, 9, e102699. [CrossRef]

112. Bond, P.; Llewellyn, W.; Van Mol, P. Anabolic androgenic steroid-induced hepatotoxicity. Med. Hypotheses 2016, 93, 150-153. [CrossRef] [PubMed]

113. Neri, M.; Bello, S.; Bonsignore, A.; Cantatore, S.; Riezzo, I.; Turillazzi, E.; Fineschi, V. Anabolic 759 androgenic steroidsabuse and liver toxicity. Mini Rev. Med. Chem. 2011, 11, 430-437. [CrossRef] [PubMed]

114. Solimini, R.; Rotolo, M.C.; Mastrobattista, L.; Mortali, C.; Minutillo, A.; Pichini, S.; Pacifici, I.; Palmi, I. Hepatotoxicity associated with illicit use of anabolican drogenic steroids in doping. Eur. Rev. Med. Pharmacol. Sci. 2017, 21 (Suppl. 1), 7-16. [PubMed]

115. Vieira, R.P.; França, R.F.; Damaceno-Rodrigues, N.R.; Dolhnikoff, M.; Caldini, E.G.; Carvalho-Pinto, R.M.; Ribeiro, W. Dose-Dependent Hepatic Response to Subchronic Administration of Nandrolone Decanoate. Med. Sci. Sports Exerc. 2008, 40, 842-847. [CrossRef]

116. Schwingel, P.A.; Cotrim, H.P.; Salles, B.R.; Almeida, C.E.; dos Santos, C.R., Jr.; Nachef, B.; Andrade, A.R.; Zoppi, C.C. Anabolic-androgenic steroids: A possible new risk factor of toxicant-associated fatty liver disease. Liver Int. 2011, 31, 348-353. [CrossRef]

117. Kalicharan, R.; Bout, M.; Oussoren, C.; Vromans, H. Where does hydrolysis of nandrolone decanoate occur in the human body after release from an oil depot? Int. J. Pharm. 2016, 515, 721-728. [CrossRef] 
118. Riezzo, I.; Turillazzi, E.; Bello, S.; Cantatore, S.; Cerretani, D.; Di Paolo, M.; Fiaschi, A.I.; Frati, P.; Neri, M.; Pedretti, M.; et al. Chronic nandrolone administration promotes oxidative stress, induction of pro-inflammatory cytokine and TNF- $\alpha$ mediated apoptosis in the kidneys of CD1 treated mice. Toxicol. Appl. Pharmacol. 2014, 280, 97-106. [CrossRef]

119. Kahal, A.; Allem, R. Reversible effects of anabolic steroid abuse on cyto-architectures of the heart, kidneys and testis in adult male mice. Biomed. Pharmacother. 2018, 106, 917-922. [CrossRef]

120. Hossein, L.; Roozbeh, J.; Sagheb, M.; Karbalay-Doust, S.; Noorafshan, A. Nandrolone decanoate increases the volume but not the length of the proximal and distal convoluted tubules of the mouse kidney. Micron 2009, 40, 226-230. [CrossRef]

121. Brasil, G.A.; Lima, E.M.; Nascimento, A.M.D.; Caliman, I.F.; De Medeiros, A.R.S.; Silva, M.S.B.; De Abreu, G.R.; Dos Reis, A.M.; Andrade, T.U.; Bissoli, N.S. Nandrolone decanoate induces cardiac and renal remodeling in female rats, without modification in physiological parameters: The role of ANP system. Life Sci. 2015, 137, 65-73. [CrossRef]

122. Bertozzi, G.; Sessa, F.; Maglietta, F.; Cipolloni, L.; Salerno, M.; Fiore, C.; Fortarezza, P.; Ricci, P.; Turillazzi, E.; Pomara, C. Immunodeficiency as a side effect of anabolic androgenic steroid abuse: A case of necrotizing myofasciitis. Forensic. Sci. Med. Pathol. 2019, 15, 616-621. [CrossRef] [PubMed]

123. Kantarci, U.H.; Punduk, Z.; Senarslan, O.; Dirik, A. Evaluation of anabolic steroid induced renal damage with sonography in bodybuilders. J. Sports Med. Phys. Fit. 2018, 58, s0022-s4707. [CrossRef] [PubMed]

124. Uhlén, S.; Lindblom, J.; Kindlundh, A.; Mugisha, P.; Nyberg, F. Nandrolone treatment decreases the level of rat kidney alpha(1B)-adrenoceptors. Naunyn. Schmiedebergs Arch. Pharmacol. 2003, 368, 91-98. [CrossRef] [PubMed]

125. Fineschi, V.; Neri, M.; Di Donato, S.; Pomara, C.; Riezzo, I.; Turillazzi, E. An immunohistochemical study in a fatality due to ovarian hyper stimulation syndrome. Int. J. Leg. Med. 2006, 120, 293-299. [CrossRef]

126. Socas, L.; Zumbado, M.; Pérez-Luzardo, O.; Ramos, A.; Pérez, C.; Hernández, J.R.; Boada, L.D. Hepatocellular adenomas associated with anabolic androgenic steroid abuse in bodybuilders: A report of two cases and a review of the literature. Br. J. Sports Med. 2005, 39, e27. [CrossRef]

127. Ma, W.-L.; Lai, H.-C.; Yeh, S.; Cai, X.; Chang, C. Androgen receptor roles in hepatocellular carcinoma, fatty liver, cirrhosis and hepatitis. Endocr-Relat. Cancer 2014, 21, R165-R182. [CrossRef]

128. Singh, V.; Batta, A. Suspected reactivation of extra pulmonary tuberculosis focus after non-medical abuse of anabolic androgenic steroids: A case report. J. Basic Clin. Physiol. Pharmacol. 2019, 31, 20190167. [CrossRef]

129. Calabrese, L.H.; Kleiner, S.M.; Barna, B.P.; Skibinski, C.I.; Kirkendall, D.T.; Lahita, R.G.; Lombardo, J.A. The effects of anabolic steroids and strength training on the human immune response. Med. Sci. Sports Exerc. 1989, 21, 386-392. [CrossRef]

130. Kanda, N.; Tsuchida, T.; Tamaki, K. Testosterone inhibits immunoglobulin production by human peripheral blood mononuclear cells. Clin. Exp. Immunol. 1996, 106, 410-415. [CrossRef]

131. Alén, M.; Reinilä, M.; Vihko, R. Response of serum hormones to and rogen administration in power athletes. Med. Sci. Sports Exerc. 1985, 17, 354-359.

132. Hartgens, F.; Hamulyak, K.; Pernot, C.; Willems, S.M. Effects of high dosesandrogenic-anabolicsteroids on haematoglicparameters in bodybuilders. In Proceedings of the 8th FIMS European Sports Medicine Congress, Granada, Spain, 23-27 October 1995.

133. Hughes, T.K.; Fulep, E.; Juelich, T.; Smith, E.M.; Stanton, G. Modulation of immune responses by anabolic androgenic steroids. Int. J. Immunopharmacol. 1995, 17, 857-863. [CrossRef]

134. Salerno, M.; Cascio, O.; Bertozzi, G.; Sessa, F.; Messina, A.; Monda, V.; Cipolloni, L.; Biondi, A.; Daniele, A.; Pomara, C. Anaboli candrogenic steroids and carcinogenicity focusing on Leydigcell: A literature review. Oncotarget 2018, 9, 19415. [CrossRef] [PubMed]

135. Tentori, L.; Graziani, G. Doping with growth hormone/IGF-1, anabolic steroids or erythropoietin: Is there a cancer risk? Pharmacol. Res. 2007, 55, 359-369. [CrossRef]

136. Kara, M.; Ozcagli, E.; Fragkiadaki, P.; Kotil, T.; Stivaktakis, P.D.; Spandidos, D.A.; Tsatsakis, A.M.; Alpertunga, B. Determination of DNA damage and telomerase activity in stanozolol-treated rats. Exp. Ther. Med. 2016, 13, 614-618. [CrossRef] [PubMed]

137. Trepel, J.B.; Mollapour, M.; Giaccone, G.; Neckers, L. Targeting the dynamic HSP90 complex in cancer. Nat. Rev. Cancer 2010, 10, 537-549. [CrossRef] 
138. Dodge, T.; Hoagland, M.F. The Use of Anabolic Androgenic Steroidsand Polypharmacy: A Review of the Literature. Drug Alcohol. Depend 2011, 114, 100-109. [CrossRef]

139. Schulze, J.J.; Rane, A.; Ekström, L. Genetic variation in androgen disposition: Implications in clinical medicine including testosterone abuse. Expert Opin. Drug Metab. Toxicol. 2009, 5, 731-744. [CrossRef]

Publisher's Note: MDPI stays neutral with regard to jurisdictional claims in published maps and institutional affiliations.

(C) 2020 by the authors. Licensee MDPI, Basel, Switzerland. This article is an open access article distributed under the terms and conditions of the Creative Commons Attribution (CC BY) license (http://creativecommons.org/licenses/by/4.0/). 